\title{
Opportunities and Barriers of Hydrogen-Electric Hybrid Powertrain Vans: A Systematic Literature Review
}

\author{
Oscar Castillo $^{1}$, Roberto Álvarez ${ }^{1, *}$ and Rosario Domingo ${ }^{2}$ (D) \\ 1 Department of Industrial Engineering, Universidad Nebrija, C/Pirineos 55, 28040 Madrid, Spain; \\ ocastilloc@alumnos.nebrija.es \\ 2 Department of Construction and Manufacturing Engineering, Universidad Nacional de Educación a \\ Distancia (UNED), C/Juan del Rosal 12, 28040 Madrid, Spain; rdomingo@ind.uned.es \\ * Correspondence: ralvarez@nebrija.es
}

Received: 2 August 2020; Accepted: 4 October 2020; Published: 7 October 2020

\begin{abstract}
The environmental impact of the road transport sector, together with urban freight transport growth, has a notable repercussions in global warming, health and economy. The need to reduce emissions caused by fossil fuel dependence and to foster the use of renewable energy sources has driven the development of zero-emissions powertrains. These clean transportation technologies are not only necessary to move people but to transport the increasing demand for goods and services that is currently taking place in the larger cities. Full electric battery-powered vans seem to be the best-placed solution to the problem. However, despite the progress in driving range and recharge options, those and other market barriers remain unsolved and the current market share of battery electric vehicles (BEVs) is not significant. Based on the development of hydrogen fuel cell stacks, this work explains an emerging powertrain architecture concept for N1 class type vans, that combines a battery-electric configuration with a fuel cell stack powered by hydrogen that works as a range extender (FC-EREV). A literature review is conducted, with the aim to shed light on the possibilities of this hybrid light-duty commercial van for metropolitan delivery tasks, providing insights into the key factors and issues for sizing the powertrain components and fuel management strategies to meet metropolitan freight fleet needs.
\end{abstract}

Keywords: hydrogen; range extender; fuel cell; light commercial vehicles; medium-duty vehicles; urban freight transport; urban logistics; sustainable city logistics; last-mile delivery; delivery van

\section{Introduction}

Nowadays, energy efficiency and sustainability are critical objectives in the value chain of business activities. Manufacturing and logistics are key links in this chain. According to International Energy Agency (IEA) and European Environment Agency (EEA) data, at the end of the year 2017, the world-level energy consumption for the industry and transport sectors were almost the same, around $12.6 \mathrm{ZJ}$, nevertheless, $\mathrm{CO}_{2}$ emissions for industry and transport were around $6.2 \mathrm{Mt}$ of $\mathrm{CO}_{2}$ and $8 \mathrm{Mt}$ of $\mathrm{CO}_{2}$ respectively. However, what is more interesting, observe the trend curves of energy consumption and $\mathrm{CO}_{2}$ emissions, which, for industry, has been similar since 2011, however, in the transport sector, it is continuously growing. In particular, if we focus on road transport share of greenhouse gas emissions in the EU28 zone, according to EEA data, is observed that this means of transport has the most important impact with $71.7 \%$. The environmental impact of road transport takes on special relevance in metropolitan areas [1], mainly due to the high rate of economic activities and population concentrated in these areas. The segment of road freight transport whose activities are focused on pick-up and delivery activities in metropolitan areas is known as Urban Freight Transport 
(UFT). The key objective of UFT is to carry goods to the end of the supply chain throughout commercial vehicle fleets. UFT is considered a complex task because the delivery acts performed are in most cases composed of heterogeneous loads (different types and amount of objects, different sizes and weights), multiple delivery points and a great mileage to be covered. In recent years, there has been an increasing demand for UFT services supported by two main influence factors:

- The growth of the city areas and urban population [2]. It is a fact that this phenomenon has been growing continuously since 1950 . Over $50 \%$ of the global population has lived in in urban areas [3] since 2007, and the trend evolution projects that $60 \%$ of the global population will live in cities by 2030. The number of mega-cities (cities with a population of over ten million people) expected by 2030 could reach 41 [4]. One of the consequences, among others, is the inevitable impact in greenhouse gas and pollutant emissions, opening the discussion about the measures that have to be taken to achieve the abatement of the emissions caused by the road transport.

- The new business opportunities offered by e-commerce. The European business-to-consumer (B2C) ecommerce turnover has practically doubled from 2013 to 2018. Not much is certain today, but the buying behavior after COVID-19 will rely heavily on e-commerce.

From the authors' point of view, an increasing and uncontrolled volume of UFT services may cause environmental, health and economic consequences, such as traffic congestion, pollutant emissions (both emissions and noises), energy inefficiencies, road accidents, infrastructure degradation and parking and land space for transport facilities instead of other purposes. On the other hand, greenhouse gas emissions linked to road transport in light commercial vehicles are continuously rising. As an illustrative example, the EU27 greenhouse gas emissions (GHG) caused by road transport in 2018 were $26.8 \%$ higher than the 1990 s and, particularly, taking as a reference the latest EEA data in light-duty trucks, the growth reached $56.5 \%$ This worrying situation has spurred EU governments to engage with road transport environmental policies, such as forecasting low emissions areas and emission tolls, among others, aiming to reduce carbon dioxide emissions by $60 \%$ relative to 1990 levels by 2050 [5]. All these reasons lead to a transition towards lower emission vehicle technologies, aiming to reach a sustainable urban freight transport model with efficient energy consumption and the same time achieving low environmental impacts.

Environmental policies combined with the permanent and unwavering objective of reduction in costs, because of the high cost shareof last-mile delivery in the transport process [6], are pushing the logistic companies to search for solutions for improving their overall efficiency and, at the same time, to minimize the environmental impact caused as a consequence of these activities. Currently, delivery management software (DMS) is widely used to enhance the logistic activities through tracking deliveries, delivery task management, route optimization and collecting data for the evaluation of delivery activity performances. The other face of the solution to address these challenges is based on the progressive substitution of internal combustion vehicles (ICVs) by electric vehicles (EVs) when replacing units of their urban freight delivery fleets. Electric vans could be a good option for a van fleet with a large number of vehicles, high annual mileage per vehicle, route planning and low speed profiles. These working conditions would lead to low running costs and facilitate the introduction of electric powertrains. Despite the advantageous conditions for using EVs in UFT and several governmental actions boosting their market spread, such as subsidies for the purchase of these vehicles, tax exemptions and other non-financial policies (as preferential parking zones, free access to low emissions restricted urban areas, among others), market sale evolution of electric light commercial vehicles has not been fast enough. In accordance with 2019 European Automobile Manufacturers Association (ACEA) data statistics, almost $93 \%$ of new registrations in light commercial vehicles across the European Community have a diesel powertrain and the future outlook is not very encouraging [7]. However, there is significant literature and demonstrative projects that further explore and analyze the feasibility of employing different EV technologies in passengers and commercial vehicles (Table 1). In light-duty vehicle class, battery electric vehicles (BEVs) attract all the attention, nevertheless, little 
attention has been paid to other available electric powertrain configurations that would be of possible interest for UFT activities. This is the case of electricity/hydrogen hybridization and specifically the use of hydrogen, in combination with electricity, in a range extender powertrain (FC-EREV) with an energy-managing strategy designed to overcome the main operational limitations: the range and the recharging time in the case of battery electric vehicles, and the lack of refueling infrastructure in the case of hydrogen. Taking into account European Alternative Fuels Observatory (EAFO) data, there are near 195,000 public charging stations across EU-33 countries, mostly concentrated in five countries, and approximately $90 \%$ are power chargers with less than $22 \mathrm{~kW}$ of output power. The case of hydrogen filling stations are even worse, there are only 124 filling stations in EU-33, most of them concentrated in Germany. There are other particular barriers related to technological, economic and environmental issues affecting BEV and FCEV technologies to a greater or lesser extent that affect their market success and could be solved with a fuel cell range extender powertrain (FC-EREV).

Table 1. Summary of literature reviews of electric vehicle (EV) market feasibility in urban transport over the last years. Type of vehicle powertrains showed: alternative fuel vehicles (AFV), battery electric vehicles (BEV) and fuel cell electric vehicles (FCEV).

\begin{tabular}{ccc}
\hline $\begin{array}{c}\text { Authors, Year, Ref. } \\
\text { (Ref., Year) }\end{array}$ & Vehicle Type & Powertrain \\
\hline Steenberghen et al., 2008 [8] & Passenger \& commercial vehicles & AFV \\
Pelletier et al., 2016 [9] & Commercial vehicles & BEV \\
Margaritis et al., 2016 [10] & Commercial vehicles & BEV \\
Quak et al., 2016 [11] & Commercial vehicles & BEV \\
Christensen et al., 2017 [12] & Passenger \& commercial vehicles & BEV \\
Birky et al., 2017 [13] & Commercial vehicles & BEV \\
J. Wang et al., 2018 [14] & Passenger vehicles & FCEV \\
Biresselioglu et al., 2018 [15] & Passenger vehicles & BEV \\
M. Wang et al., 2018 [16] & Commercial vehicles & BEV \\
\hline
\end{tabular}

An FC-EREV powertrain is composed of two subsystems, the vehicle propulsion subsystem and the range extender subsystem [17]. The electric propulsion system consists of an electric motor, a power converter and a battery pack. The range extender basic components are the hydrogen tanks, the fuel cell stack and a fuel cell boost converter. The fuel cell is the range extender, it powers the battery, keeping the state of charge (SoC) value according to an energy management strategy. There are two main operating strategies, charge depleting (CD) and charge sustaining (CS) modes. Usually, range extender configurations are designed to work with a blended battery energy management. In this way, the vehicle initially drives in $C D$ mode until the battery SoC is under a certain value, in that moment the fuel cell starts working to slow down the battery discharge. The objective of this energy management strategy is to increase the vehicle range without being externally charged with electricity. Therefore, in this type of EV powertrain configuration, the electricity stored in the battery comes from the electric network (plug-in option) and from the fuel cell, powered by hydrogen (range extender option). A power control unit (PCU) electronic device manages the fuel cell and battery power outputs and at the same time the regenerative brake capability of the vehicle, according to the energy management strategy outlined. Multiple powertrain components sizing configurations are possible, such as battery capacity, volume of hydrogen tanks and fuel cell power, combined with different energy management strategies with the aim to improve the energy efficiency and allow wider ranges.

The ambition of this research work is to conduct an inquiry into the feasibility of combine hydrogen fuel cell and electric battery powertrains for UFT activities considering the fuel cell hybrid extended range electric vehicle configuration. In this powertrain, both fuels (hydrogen and electricity) manage to fulfill the vehicle requirements, such as cost of ownership, range, performance and load capacity (weight and volume). The research work presents a review of the existing literature about the use of these hybrid powertrains in light commercial vehicles in a systematic way. The method selected 
for the review has been discussed too. We have explored and analyzed the advantages, barriers and opportunities for employing this type of electric powertrain for urban delivery activities. The focus of the study is to identify gaps and limitations around the feasibility of this range extender technology in existing research studies and explore future trends. Consequently, this literature review aims to answer the following questions: (1) is it possible to state the suitability of the hydrogen fuel cell range extender powertrains for operation in light commercial vehicles for urban delivery tasks?, (2) does the literature provide information on the sizing of components of this type of powertrains to meet the requirements of metropolitan freight carriers?

This research work is organized as follows: Section 2 explains the literature review methodology. Section 3 presents a summary of the literature review results and describes how the research studies have addressed the problem. Section 4 presents a discussion to identify feasibility factors for employing a hydrogen fuel cell range extender powertrain as a suitable solution for light-duty commercial vehicles. The final section presents the main findings and the key insights for future research.

\section{Methodology}

\subsection{Scope}

The last mile delivery scenario has a lot of actors, a great variety of products and a complex operations typology [18]. Global parcel services B2C market share in America and Europe is mainly dominated by four parcel and express companies: FedEx, UPS, DHL and TNT. All of them are involved in demonstrative projects or on-road tests to study the techno-economic feasibility of using electric vans in urban delivery activities because this type of vans can allow effective reduction of running costs and help to reach the environmental objectives. The light commercial vehicles in the EU must comply with the $\mathrm{CO}_{2}$ emission target of $147 \mathrm{~g} / \mathrm{km}$ specified in regulation 2019/631 and this target will be reduced by $15 \%$ for the $2025-2029$ period. In Table 2 are summarized a sample of vehicles used during the last five years for testing purpose.

Table 2. Electric vans tested by the main parcel and express companies (Source: own development based on manufacturer websites data).

\begin{tabular}{|c|c|c|c|c|c|c|c|c|c|}
\hline & \multirow[b]{2}{*}{ Year } & \multirow[b]{2}{*}{ Manufacturer } & \multirow[b]{2}{*}{ Model } & \multirow{2}{*}{$\begin{array}{c}\text { Battery } \\
\text { Capacity } \\
\text { (kW h) }\end{array}$} & \multirow{2}{*}{$\begin{array}{c}\mathrm{H}_{2} \\
\text { Capacity } \\
(\mathbf{k g})\end{array}$} & \multirow[b]{2}{*}{$\begin{array}{l}\text { Range } \\
(\mathbf{k m})\end{array}$} & \multirow{2}{*}{$\begin{array}{l}\text { GVM } \\
\text { (3) }(\mathrm{kg})\end{array}$} & \multicolumn{2}{|c|}{ Capacity } \\
\hline & & & & & & & & $\begin{array}{l}\text { Payload } \\
\text { (kg) }\end{array}$ & $\begin{array}{c}\text { Volume } \\
\left(\mathrm{m}^{3}\right)\end{array}$ \\
\hline DHL & 2017 & Ford-StreetScooter & $\begin{array}{c}\text { WORK } \\
\text { XL }\end{array}$ & 76 & - & $200^{(1)}$ & $4050^{(4)}$ & 1150 & 20 \\
\hline DHL & 2016 & StreetScooter & $\begin{array}{c}\text { WORK } \\
\text { L } \\
\text { H2 }\end{array}$ & 40 & - & $\begin{array}{c}80^{(1)} \\
187^{(2)}\end{array}$ & 2600 & 905 & 8 \\
\hline DHL & 2019 & Ford-StreetScooter & $\begin{array}{l}\text { Panel } \\
\text { Van }\end{array}$ & 40 & 6 & $500^{(1)}$ & $4050^{(4)}$ & 800 & 10 \\
\hline FedEx & 2018 & Chanje & V8100 & 100 & - & $240^{(1)}$ & 7500 & 2700 & 19 \\
\hline UPS & 2018 & Work horse & P80-E & 62 & - & $130^{(1)}$ & 7500 & 3450 & 23 \\
\hline TNT & 2015 & Fiat & e-Ducato & 62 & - & $200^{(2)}$ & 3500 & 680 & 17 \\
\hline
\end{tabular}

(1) Maximum autonomy according to manufacturer data. (2) NDEC driving cycle. (3) GVM, gross vehicle mass rating, maximum allowable mass of the vehicle. (4) German regulation allows drive EVs up to $4250 \mathrm{~kg}$ with a class B license.

Usually, commercial vehicle classifications are based on the gross vehicle mass (GVM) rating factor. Table 3 shows the US and EU classes considered in light and light-medium commercial vehicles category. As can be seen from the table above, almost all the vehicles have a GVM bellow $7.5 \mathrm{t}$. 
Table 3. Definition of US and EU vehicle classes considered in the review.

\begin{tabular}{|c|c|c|c|c|}
\hline \multicolumn{2}{|c|}{ United States } & \multicolumn{2}{|c|}{ European Union } & \multirow{2}{*}{$\begin{array}{c}\text { Duty } \\
\text { Classification }\end{array}$} \\
\hline Vehicle Class & Mass (t) & Vehicle Class & Mass (t) & \\
\hline 1 & $\leq 2.72$ & $\mathrm{N1}$ & $<35$ & Light truck \\
\hline $2 a$ & $\leq 3.86$ & N1 & $\leq 3.5$ & Light truck \\
\hline $2 b$ & $\leq 4.54$ & & & Light/Medium truck \\
\hline 3 & $4.54-6.35$ & N2 & $\leq 12$ & Medium truck \\
\hline 4 & $6.35-7.26$ & & & Medium truck \\
\hline
\end{tabular}

If we take as a reference the Table 2 data, and according to Table 3, most of the vehicles belong to N1 or 2a-b US commercial vehicle classes, respectively. These two classes seem to be the most interesting van configurations for logistic fleet operators. This type of vehicle covers a large number of applications with different usage profiles. On the other hand, preferred vehicles tested in this category are BEV-powered, with one exception; DHL has recently tested a hydrogen fuel cell range extender.

On the other hand, the availability of BEVs in the market is still growing, despite the limited demand from the market. All the best-selling brands in the EU light commercial vehicle (LCV) market, such as Ford, Renault, VW and PSA group, have battery-electric vans in their portfolio. In the EU market, the N1 category has great importance. According to the ACEA report [19], in 2016 LCV were almost $75 \%$ of the total commercial vehicles (including buses) and nearly $11 \%$ of the total vehicles. Given ICCT statistics, in 2018, the rate grew up to $12 \%$. In this report, top-selling light commercial vehicle models in EU-28 were most of the N1 class III, such as Ford Transit, Mercedes Sprinter, Fiat Ducato, Volkswagen Transporter and Renault Master.

It seems clear that battery-electric powered vans have been the focus of great interest in urban delivery works, but there is a certain weakness that should be addressed. Particularly, the authors are hardly seeing any steps to use other electric powertrain options to solve these issues. Therefore, in the present work, the authors will perform the study mainly on the suitability of use hydrogen fuel cell range extender powertrains in light-medium commercial vehicles class for UFT tasks. Especially, those who use Li-ion batteries and PEM fuel cell stacks because of its technical characteristics and market availability [20-22].

This paper focuses on the literature review analysis of strengths, weakness and opportunities for market potential and feasibility from technical, economic and environmental (air pollution) points of view. Therefore, social and psychological factors, urban spatial issues and policy measures are not taken into account in the study. On the other hand, only local zero-emissions vehicles will be considered.

\subsection{Review Method}

To achieve the objectives of this paper, a literature review was conducted. There are different types of literature reviews [23]. Among all of them, the authors have opted for a systematic literature review with a meta-synthesis approach because this type of literature review integrates existing information in studies with diverse methodologies and provides data for rational decision making better if compared to other types of literature review methodologies [24]. The literature review method employed is based on PRISMA guidelines [25] and includes five main stages: scoping, identification, screening, eligibility and inclusion. They are summarized in a flow diagram presented in Figure 1.

For conducting the literature search it is used more representative databases, such as IEEE Explore, Springer Link, WoS and Scopus, but also Google Scholar (GS) search engine, because it is a competitive searching tool in engineering research areas [26]. 


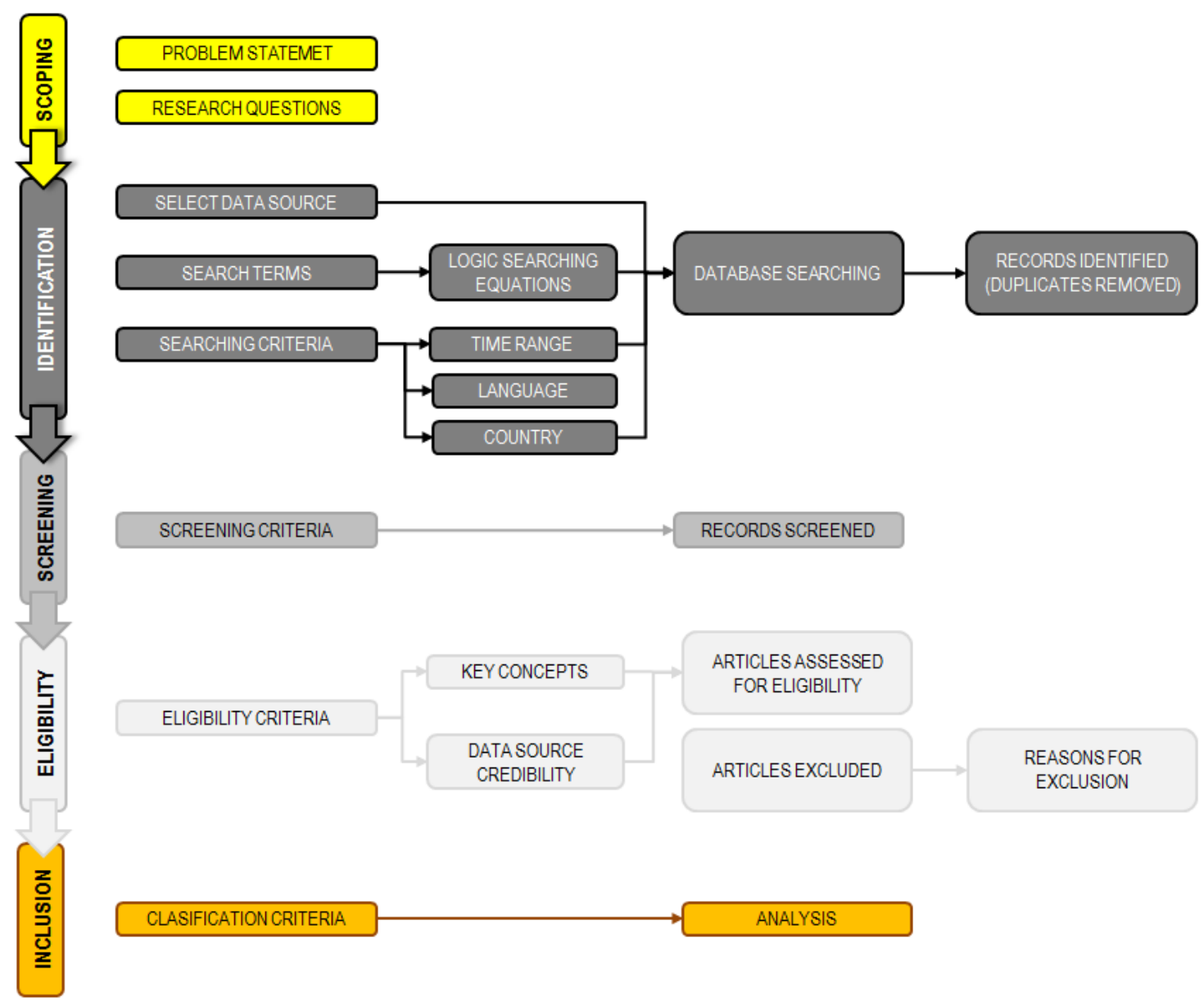

Figure 1. Flow chart from scoping to inclusion stage. Source: own development based on the PRISMA 2009 Flow Diagram [25].

\section{Results}

In order to identify the relevant studies, we employed a set of keywords including search strings combinations of the fuel cell, hydrogen, range extender, urban freight, urban logistics, city logistics, last-mile delivery, delivery van, light commercial vehicle, light and medium-duty vehicles, sustainable logistics and sustainable supply chain. They were combined using logic operators to configure searching equations. A list of keywords and search strings are provided in Appendix A (see Table A1). The search includes documents from 2006 to 2019, written in English and published in western countries. The identification phase returned a considerable amount of documents (1842 records) with the search terms included. The screening criterion was whether the study has information about the feasibility of using electric powertrain technologies in UFT, taking into account market feasibility analysis, environmental concerns (air pollution and GHG reduction), refueling and charging infrastructure issues, economic aspects or vehicle configuration technical features. The assessment is conducted through the analysis of the title and abstract sections.

The screening phase returned 449 documents, which is why for the selection of relevant articles that follow the purpose of the document, a reading of the introduction, conclusions and reference sections was performed. The eligibility criteria we tried to assess were: (1) if the document reflects discussions about aspects such as market feasibility, environmental concerns, charging infrastructure issues, economic aspects or vehicle technical features in the use of fuel cell hybrid technologies or (2) if it includes comparisons between FC and BEV technologies (light and light/medium duty vehicles) performing urban delivery tasks. Additionally, the analysis of document references makes it possible to 
find articles related to one that could be interesting for the research purpose and, in this way, expanding the number of documents for the eligibility stage. In Appendix B (see Table A2), we summarized the dimensions considered as inclusion criteria. The final number of selected studies was 41 .

This section is divided into three subsections. In the first subsection, we present an overview of the selected studies and a bibliographic analysis of these documents. In the second subsection, we present a description of the main topics the research studies have focused on and how these studies have addressed the issues. Finally, we analyzed the attributes evaluated in each reference to identify key factors and issues for using FC-EREV commercial vehicles to meet metropolitan freight carrier requirements.

\subsection{Selected Studies and Bibliographic Analysis}

A summary of the selected studies is presented in Table 4, showing the year of publication, the powertrain type studied, the analysis topic and the methodology used. Furthermore, additional information from the studies, such as publication information, SJR index, type of document, country of origin and vehicle type are provided in Appendix C (see Table A3).

Table 4. Overview of selected studies.

\begin{tabular}{|c|c|c|c|}
\hline Authors (Ref., Year) & Powertrain & Research Topic & Methodology \\
\hline $\begin{array}{c}\text { Adebusuyi et al., } 2012 \\
\text { [27] }\end{array}$ & FC-EREV & $\begin{array}{l}\text { Cost, performance and } \\
\text { efficiency analysis }\end{array}$ & Testing \\
\hline Arnhold et al., 2017 [28] & BEV and FCEV & $\begin{array}{c}\text { Market } \\
\text { potential/diffusion/feasibility }\end{array}$ & $\begin{array}{l}\text { Demonstrative projects } \\
\text { review }\end{array}$ \\
\hline Bartolozzi et al., 2013 [29] & BEV and FCEV & $\begin{array}{l}\text { Sustainability and } \\
\text { Environmental perspectives }\end{array}$ & $\begin{array}{l}\text { Modeling and } \\
\text { Simulation }\end{array}$ \\
\hline $\begin{array}{l}\text { Bergmann et al., } 2017 \\
\text { [30] }\end{array}$ & EREV & $\begin{array}{l}\text { Cost, performance and } \\
\text { efficiency analysis }\end{array}$ & $\begin{array}{l}\text { Modeling and } \\
\text { Simulation }\end{array}$ \\
\hline Juan et al., 2016 [31] & BEV and FCEV & $\begin{array}{l}\text { Sustainability and } \\
\text { Environmental perspectives }\end{array}$ & Literature review \\
\hline Kleiner et al., 2017a [7] & AFV & $\begin{array}{c}\text { Market } \\
\text { potential/diffusion/feasibility }\end{array}$ & $\begin{array}{l}\text { Modeling and } \\
\text { Simulation }\end{array}$ \\
\hline Kleiner et al., 2017b [32] & AFV & $\begin{array}{l}\text { Cost, performance and } \\
\text { efficiency analysis }\end{array}$ & $\begin{array}{l}\text { Modeling and } \\
\text { Simulation }\end{array}$ \\
\hline Kleiner et al., 2015 [33] & BEV and FCEV & $\begin{array}{l}\text { Cost, performance and } \\
\text { efficiency analysis }\end{array}$ & $\begin{array}{c}\text { Demonstrative projects } \\
\text { review }\end{array}$ \\
\hline Millo et al., 2016 [34] & FC-EREV & $\begin{array}{l}\text { Powertrain and Battery } \\
\text { Systems }\end{array}$ & $\begin{array}{l}\text { Modeling and } \\
\text { Simulation }\end{array}$ \\
\hline $\begin{array}{c}\text { Ntziachristos et al., } 2012 \\
\text { [35] }\end{array}$ & $\mathrm{AFV}$ & $\begin{array}{l}\text { Cost, performance and } \\
\text { efficiency analysis }\end{array}$ & Literature review \\
\hline Özdemir et al., 2015 [36] & BEV and FCEV & $\begin{array}{l}\text { Cost, performance and } \\
\text { efficiency analysis }\end{array}$ & Literature review \\
\hline Propfe et al., 2011 [37] & BEV and FCEV & $\begin{array}{l}\text { Sustainability and } \\
\text { Environmental perspectives }\end{array}$ & $\begin{array}{l}\text { Modeling and } \\
\text { Simulation }\end{array}$ \\
\hline Wood et al., 2013 [38] & FC-EREV & $\begin{array}{c}\text { Market } \\
\text { potential/diffusion/feasibility }\end{array}$ & $\begin{array}{l}\text { Modeling and } \\
\text { Simulation }\end{array}$ \\
\hline Ruf et al., 2017 [39] & FC-EREV & $\begin{array}{c}\text { Market } \\
\text { potential/diffusion/feasibility }\end{array}$ & $\begin{array}{c}\text { Demonstrative projects } \\
\text { review }\end{array}$ \\
\hline $\begin{array}{l}\text { Van Mierlo et al., } 2006 \\
\text { [40] }\end{array}$ & BEV and FCEV & $\begin{array}{c}\text { Market } \\
\text { potential/diffusion/feasibility }\end{array}$ & Literature review \\
\hline Offer et al., 2010 [41] & FC-PHEV & $\begin{array}{l}\text { Cost, performance and } \\
\text { efficiency analysis }\end{array}$ & Literature review \\
\hline Thomas, 2009 [42] & BEV and FCEV & $\begin{array}{l}\text { Sustainability and } \\
\text { Environmental perspectives }\end{array}$ & $\begin{array}{l}\text { Modeling and } \\
\text { Simulation }\end{array}$ \\
\hline Thomas, 2009 [43] & $\mathrm{AFV}$ & $\begin{array}{l}\text { Sustainability and } \\
\text { Environmental perspectives }\end{array}$ & $\begin{array}{l}\text { Modeling and } \\
\text { Simulation }\end{array}$ \\
\hline $\begin{array}{l}\text { Kelouwani et al., } 2013 \\
\text { [23] }\end{array}$ & FC-PHEV & $\begin{array}{l}\text { Cost, performance and } \\
\text { efficiency analysis }\end{array}$ & $\begin{array}{l}\text { Modeling and } \\
\text { Simulation }\end{array}$ \\
\hline
\end{tabular}


Table 4. Cont

\begin{tabular}{|c|c|c|c|}
\hline Authors (Ref., Year) & Powertrain & Research Topic & Methodology \\
\hline Robinius et al., 2018 [44] & BEV and FCEV & Charging infrastructures & $\begin{array}{l}\text { Modeling and } \\
\text { Simulation }\end{array}$ \\
\hline Baptista et al., 2010b [45] & FC-PHEV & $\begin{array}{c}\text { Market } \\
\text { potential/diffusion/feasibility }\end{array}$ & $\begin{array}{l}\text { Modeling and } \\
\text { Simulation }\end{array}$ \\
\hline Jensen et al., 2013 [46] & FC-EREV & $\begin{array}{c}\text { Powertrain and Battery } \\
\text { Systems }\end{array}$ & $\begin{array}{l}\text { Modeling and } \\
\text { Simulation }\end{array}$ \\
\hline Kromer et al., 2007 [47] & BEV and FCEV & $\begin{array}{c}\text { Market } \\
\text { potential/diffusion/feasibility }\end{array}$ & $\begin{array}{l}\text { Modeling and } \\
\text { Simulation }\end{array}$ \\
\hline Sharer et al., 2013 [48] & FC-EREV & $\begin{array}{l}\text { Cost, performance and } \\
\text { efficiency analysis }\end{array}$ & $\begin{array}{l}\text { Modeling and } \\
\text { Simulation }\end{array}$ \\
\hline Jokela et al., 2019 [25] & FC-EREV & $\begin{array}{l}\text { Cost, performance and } \\
\text { efficiency analysis }\end{array}$ & $\begin{array}{l}\text { Modeling and } \\
\text { Simulation }\end{array}$ \\
\hline Sim et al., 2019 [49] & FC-EREV & $\begin{array}{l}\text { Cost, performance and } \\
\text { efficiency analysis }\end{array}$ & $\begin{array}{l}\text { Modeling and } \\
\text { Simulation }\end{array}$ \\
\hline Walters et al., 2015 [24] & FC-EREV & $\begin{array}{l}\text { Cost, performance and } \\
\text { efficiency analysis }\end{array}$ & $\begin{array}{l}\text { Modeling and } \\
\text { Simulation }\end{array}$ \\
\hline $\begin{array}{l}\text { Fernández et al., } 2016 \\
\text { [17] }\end{array}$ & FC-EREV & $\begin{array}{l}\text { Cost, performance and } \\
\text { efficiency analysis }\end{array}$ & $\begin{array}{l}\text { Modeling and } \\
\text { Simulation }\end{array}$ \\
\hline Wu et al., 2019 [50] & FC-EREV & $\begin{array}{l}\text { Cost, performance and } \\
\text { efficiency analysis }\end{array}$ & Literature review \\
\hline Bendjedia et al., 2018 [51] & FC-EREV & $\begin{array}{l}\text { Powertrain and Battery } \\
\text { Systems }\end{array}$ & $\begin{array}{l}\text { Modeling and } \\
\text { Simulation }\end{array}$ \\
\hline Baptista et al., 2010a [52] & FC-EREV & $\begin{array}{l}\text { Sustainability and } \\
\text { Environmental perspectives }\end{array}$ & $\begin{array}{l}\text { Modeling and } \\
\text { Simulation }\end{array}$ \\
\hline Álvarez et al., 2018 [53] & FC-EREV & $\begin{array}{l}\text { Cost, performance and } \\
\text { efficiency analysis }\end{array}$ & $\begin{array}{l}\text { Modeling and } \\
\text { Simulation }\end{array}$ \\
\hline Browne et al., 2014 [54] & AFV & $\begin{array}{c}\text { Sustainability and } \\
\text { Environmental perspectives }\end{array}$ & $\begin{array}{c}\text { Demonstrative projects } \\
\text { review }\end{array}$ \\
\hline Lewis et al., 2017 [55] & FC-EREV & $\begin{array}{l}\text { Cost, performance and } \\
\text { efficiency analysis }\end{array}$ & $\begin{array}{l}\text { Modeling and } \\
\text { Simulation }\end{array}$ \\
\hline $\begin{array}{c}\text { Steenberghen et al., } 2008 \\
\text { [8] }\end{array}$ & AFV & $\begin{array}{c}\text { Market } \\
\text { potential/diffusion/feasibility }\end{array}$ & Literature review \\
\hline $\begin{array}{c}\text { Ramachandran et al., } \\
2015 \text { [56] }\end{array}$ & AFV & $\begin{array}{l}\text { Sustainability and } \\
\text { Environmental perspectives }\end{array}$ & $\begin{array}{l}\text { Modeling and } \\
\text { Simulation }\end{array}$ \\
\hline Ceraolo et al., 2017 [57] & PHEV & $\begin{array}{l}\text { Cost, performance and } \\
\text { efficiency analysis }\end{array}$ & $\begin{array}{l}\text { Modeling and } \\
\text { Simulation }\end{array}$ \\
\hline Hardman et al., 2013 [58] & BEV and FCEV & $\begin{array}{c}\text { Market } \\
\text { potential/diffusion/feasibility }\end{array}$ & Literature review \\
\hline $\begin{array}{c}\text { Maniatopoulos et al., } \\
2015 \text { [59] }\end{array}$ & BEV and FCEV & $\begin{array}{l}\text { Sustainability and } \\
\text { Environmental perspectives }\end{array}$ & $\begin{array}{l}\text { Modeling and } \\
\text { Simulation }\end{array}$ \\
\hline Jones et al., 2020 [60] & BEV and FCEV & $\begin{array}{l}\text { Cost, performance and } \\
\text { efficiency analysis }\end{array}$ & Testing \\
\hline $\begin{array}{l}\text { Le Duigou et al., } 2014 \\
\text { [61] }\end{array}$ & FC-EREV & $\begin{array}{l}\text { Cost, performance and } \\
\text { efficiency analysis }\end{array}$ & $\begin{array}{l}\text { Modeling and } \\
\text { Simulation }\end{array}$ \\
\hline
\end{tabular}

The relevant documents found have been classified to carry out further analysis. The basic characteristics used for the classification are:

- Number fraction of documents published from 2006 to 2019 (Figure 2a).

- Number fraction of documents published per country (Figure $2 b$ ).

- Number fraction of documents published per analysis topic (Figure 2c).

- Number fraction of documents published per powertrain configuration (Figure 2d).

- Number fraction of articles published per type of document (Figure 2e).

- Number fraction of articles published per type of methodology used to address the issue (Figure 2f).

- Number fraction of articles published per type of vehicle class (Figure 2g). 
The results included in Figure 2a-g show that most of the documents available were written from 2013 to 2019, in scientific journal article format, principally published in Germany, US and UK, focused on light-duty vehicles (passengers and commercial use) with topics related with economic aspects, market feasibility and environmental perspectives and focused on battery and fuel cell competitiveness or hybrid-electric commercial vehicles using modeling or simulation methodologies.

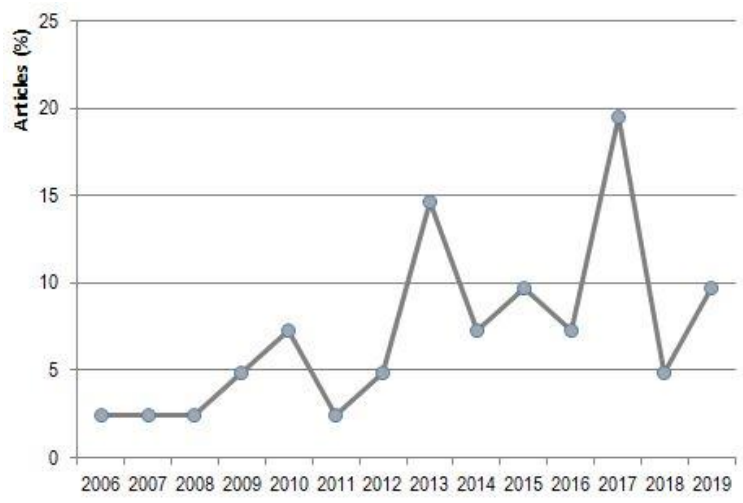

(a)

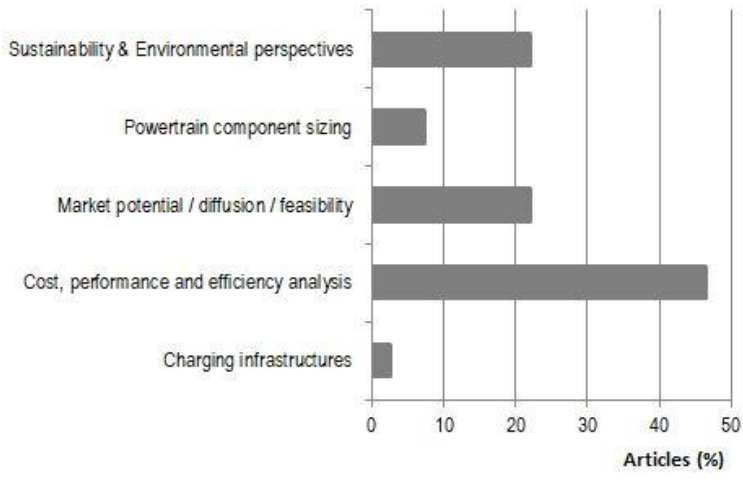

(c)

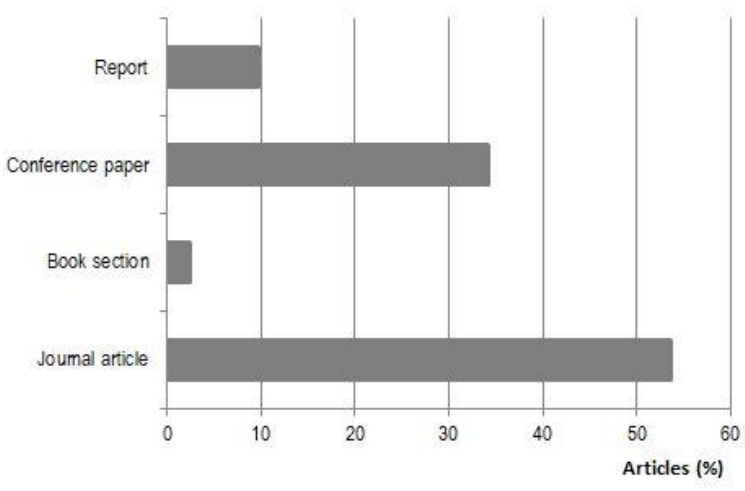

(e)

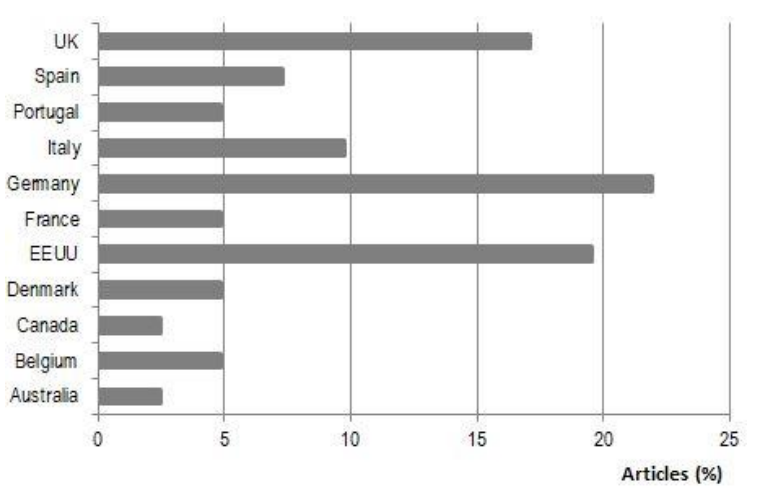

(b)

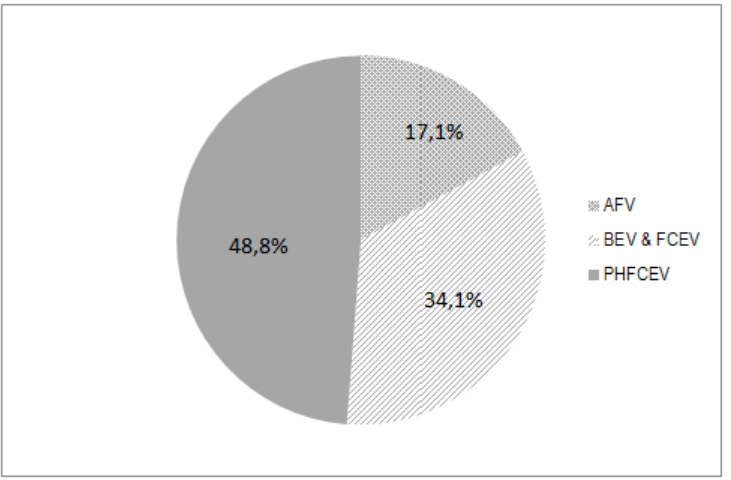

(d)

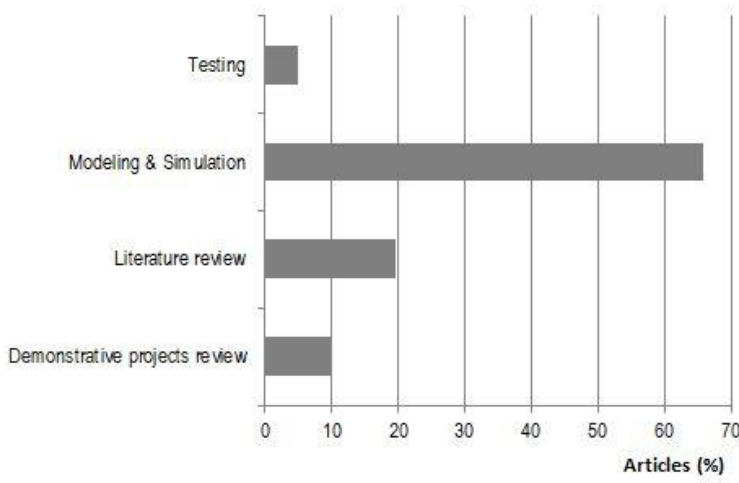

(f)

Figure 2. Cont. 


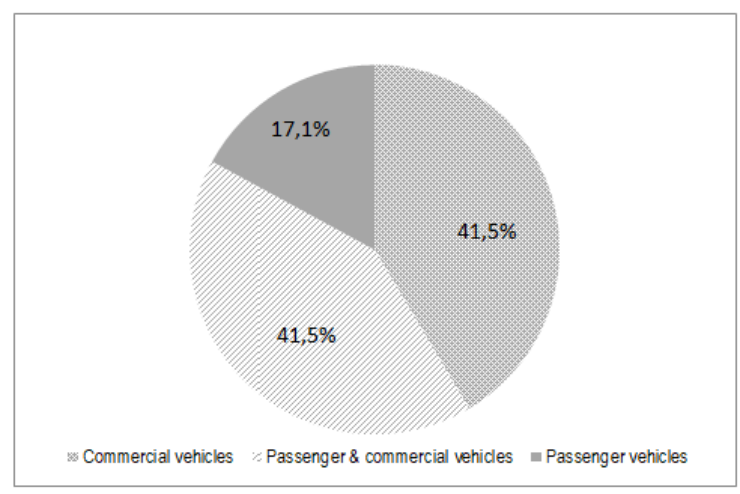

$(\mathrm{g})$

Figure 2. Published documents: (a) number fraction of published documents by year; (b) number fraction of published documents by country; (c) number fraction of published documents by topic analyzed; (d) number fraction of published documents by type of powertrain; (e) number fraction of published documents by type of document; (f) number fraction of published documents by type of methodology used; (g) number fraction of published documents by type of vehicle class.

\subsection{Summary of Results of the Main Research Topics. Methodology Used to Address the Issues}

The thematic description of the reviewed articles involves three main aspects: research topic, powertrain configuration studied and approach or method used. The data analysis reveals that the research topic of the selected documents has focused mainly on five aspects: cost, performance and efficiency analysis, market potential and environmental perspectives. On the other hand, powertrain components sizing and related technical features, and refueling infrastructure topics have been less investigated. The first of these topics focuses on the techno-economic impacts of different powertrain configurations in several attributes, such as the cost of ownership, range, payload and vehicle performances, among others. The second topic focuses on the feasibility of using EVs in UFT based on their business strengths and weakness. The third topic focuses on environmental issues, basically air pollution impacts. In the fourth topic, technical aspects of electric powertrain components are under study, basically energy storage devices and energy management strategies. Finally, the fifth one takes into account charging and refueling infrastructures, which are essential for the day-to-day operation of a logistic vehicle fleet for an urban delivery business. On the other hand, while the selected studies have conducted their research work using mainly model and simulation tool, in contrast, experimental tests are much less used. In Appendix D (see Tables A4-A8) we showed the selected documents sorted by methodology and an overview of the research challenges addressed.

\subsection{Identification of Key Features Evaluated in the Selected Studies}

The key topics analyzed are classified into three areas: economic, technical and operational. These techno-economic and operational issues are of particular interest to give an answer to the user requirements. The analysis of the state of the art reported in Appendix D (see Tables A4-A8) has led to generate a list of attributes linked to the key topics. Each area shows specific attributes:

- Economic attributes: purchase price and operational costs.

- Technological attributes: range, environmental efficiency and vehicle performances.

- Operational attributes: refueling infrastructure, refueling time, fuel cost, fuel production, usage intensity and route planning.

Table 5 summarizes a description of the attributes evaluated. Finally, Table 6 shows an overview of the attributes evaluated in each reference. As can be seen, financial and technological features are the most studied in the literature. In contrast, operational features have received less attention. 
Table 5. Description of the attributes evaluated.

\begin{tabular}{|c|c|}
\hline Attributes & Description \\
\hline Purchase price & $\begin{array}{l}\text { The acquisition cost of the vehicle is an essential part of the whole life of } \\
\text { ownership cost and is also affected by the aids for the purchase and legal fees and } \\
\text { taxes. }\end{array}$ \\
\hline Operational costs & $\begin{array}{l}\text { The running costs are mainly dependent of annual mileages, fuel cost, road and } \\
\text { parking taxes, maintenance and insurance costs. }\end{array}$ \\
\hline Range & $\begin{array}{c}\text { Total vehicle range measured in specific conditions, such as NDEC and WLTC } \\
\text { driving cycles. }\end{array}$ \\
\hline Environmental efficiency & $\begin{array}{c}\text { Data related to whole life cycle emissions analysis, well-to-wheel (WtW) or } \\
\text { tank-to-wheel (TtW) studies. }\end{array}$ \\
\hline Vehicle performances & $\begin{array}{l}\text { This factor concerns to payload (load and volume capacity), driving speed, } \\
\text { acceleration, maximum gradeability and powertrain configuration (energy } \\
\text { storage systems, energy management strategies) }\end{array}$ \\
\hline Refueling infrastructure & Recharge and refueling issues. \\
\hline Refueling time & Time needed to get full vehicle range. \\
\hline Fuel cost & $\begin{array}{l}\text { Costs associated with the production, transportation, storage and delivery of fuel } \\
\text { to the vehicle. }\end{array}$ \\
\hline Fuel production & Facts related to fuel production and supply issues. \\
\hline Usage intensity & $\begin{array}{c}\text { This factor includes duty cycle characteristics, such as daily trips, route profile } \\
\text { (slope), nominal load (usually a payload factor of } 50 \% \text { is considered), driving } \\
\text { style and ambient conditions (hot or cold temperatures), and reliability and dealer } \\
\text { support over the vehicle service life. }\end{array}$ \\
\hline Route planning & $\begin{array}{l}\text { Daily on-road route plan involving several delivery points taking into account } \\
\text { several constraints (e.g., time, distance and vehicle characteristics). }\end{array}$ \\
\hline
\end{tabular}


Table 6. List of attributes evaluated in the selected studies.

\begin{tabular}{|c|c|c|c|c|c|c|c|c|c|c|c|}
\hline \multirow[b]{2}{*}{ Authors } & \multicolumn{2}{|c|}{ Economic Features } & \multicolumn{3}{|c|}{ Technological Features } & \multicolumn{6}{|c|}{ Operational Features } \\
\hline & $\begin{array}{l}\text { Purchase } \\
\text { Price }\end{array}$ & $\begin{array}{l}\text { Operational } \\
\text { Costs }\end{array}$ & Range & $\begin{array}{c}\text { Environmental } \\
\text { Efficiency }\end{array}$ & $\begin{array}{c}\text { Vehicle } \\
\text { Performances }\end{array}$ & $\begin{array}{c}\text { Refueling } \\
\text { Infrastructure }\end{array}$ & $\begin{array}{l}\text { Refueling } \\
\text { Time }\end{array}$ & $\begin{array}{l}\text { Fuel } \\
\text { Cost }\end{array}$ & $\begin{array}{c}\text { Fuel } \\
\text { Production }\end{array}$ & $\begin{array}{c}\text { Usage } \\
\text { Intensity }\end{array}$ & $\begin{array}{c}\text { Route } \\
\text { Planning }\end{array}$ \\
\hline Adebusuyi et al., 2012 [27] & & $x$ & $x$ & & & & & $x$ & & & \\
\hline Arnhold et al., 2017 [28] & & $x$ & $X$ & & & $x$ & $x$ & & & & \\
\hline Bartolozzi et al., 2013 [29] & & & & $x$ & & & & & $x$ & & \\
\hline Bergmann et al., 2017 [30] & & $x$ & $x$ & & $x$ & & & $x$ & & $x$ & \\
\hline Juan et al., 2016 [31] & & $x$ & & $x$ & & $x$ & & & & & $x$ \\
\hline Kleiner et al., 2017a [7] & $x$ & $x$ & & $x$ & & $x$ & & $x$ & & $x$ & \\
\hline Kleiner et al., 2017b [32] & & $X$ & & & & & & & & & \\
\hline Kleiner et al., 2015 [33] & $x$ & $x$ & $\mathrm{X}$ & & $x$ & & & $x$ & & & \\
\hline Millo et al., 2016 [34] & & & $X$ & & $x$ & & & & & & \\
\hline Ntziachristos et al., 2012 [35] & $x$ & $x$ & $X$ & $x$ & $x$ & & & & & & \\
\hline Özdemir et al., 2015 [36] & & & $x$ & & $x$ & & & & & & \\
\hline Propfe et al., 2011 [37] & $x$ & $x$ & $X$ & $x$ & $x$ & & & & & & \\
\hline Wood et al., 2013 [38] & $x$ & $x$ & $X$ & & $X$ & & & $x$ & & & \\
\hline Ruf et al., 2017 [39] & $x$ & $x$ & $x$ & $x$ & & & & & & & \\
\hline Van Mierlo et al., 2006 [40] & $x$ & $x$ & & $x$ & & & & & & & \\
\hline Offer et al., 2010 [41] & $x$ & $x$ & & & $x$ & $x$ & & $x$ & & & \\
\hline Thomas, 2009 [42] & $x$ & $x$ & $x$ & $x$ & $x$ & $x$ & $x$ & $x$ & $x$ & & \\
\hline Thomas, 2009 [43] & & & & $x$ & & & & & $x$ & & \\
\hline Kelouwani et al., 2013 [23] & & & & & $x$ & & & & & & \\
\hline Robinius et al., 2018 [44] & & & & & & $x$ & & & & & \\
\hline Baptista et al., 2010b [45] & & & & $x$ & & & & $x$ & & & \\
\hline Jensen et al., 2013 [46] & & & $x$ & & $x$ & & & & & $x$ & \\
\hline Kromer et al., 2007 [47] & $x$ & $x$ & $X$ & $x$ & $X$ & & & & & & \\
\hline Sharer et al., 2013 [48] & $x$ & $x$ & $x$ & & $x$ & & & $x$ & & & \\
\hline Jokela et al., 2019 [25] & $x$ & $x$ & $x$ & & $x$ & & & $x$ & & $x$ & \\
\hline Sim et al., 2019 [49] & $x$ & $x$ & $x$ & & $x$ & & & $x$ & & & \\
\hline Walters, et al., 2015 [24] & & & $x$ & & $x$ & & & & & & \\
\hline Fernandez et al., 2016 [17] & & & $x$ & & $x$ & & & & & & \\
\hline Wu et al., 2019 [50] & $x$ & & $x$ & $x$ & $x$ & $x$ & & $x$ & $x$ & & \\
\hline Bendjedia et al., 2018 [51] & & & $x$ & & $\mathrm{X}$ & & & & & & \\
\hline Baptista et al., 2010a [52] & & & & $x$ & & & & & $x$ & & \\
\hline Álvarez et al., 2018 [53] & & & $x$ & & $x$ & & & & & & \\
\hline Browne at al., 2014 [54] & & & $x$ & $x$ & & & & & & $x$ & \\
\hline Lewis et al., 2017 [55] & & & $x$ & & $x$ & & & & & $x$ & \\
\hline Steenberghen et al., 2008 [8] & & & & $x$ & & $x$ & & & $x$ & & \\
\hline
\end{tabular}


Table 6. Cont.

\begin{tabular}{|c|c|c|c|c|c|c|c|c|c|c|c|}
\hline \multirow[b]{2}{*}{ Authors } & \multicolumn{2}{|c|}{ Economic Features } & \multicolumn{3}{|c|}{ Technological Features } & \multicolumn{6}{|c|}{ Operational Features } \\
\hline & $\begin{array}{l}\text { Purchase } \\
\text { Price }\end{array}$ & $\begin{array}{l}\text { Operational } \\
\text { Costs }\end{array}$ & Range & $\begin{array}{l}\text { Environmental } \\
\text { Efficiency }\end{array}$ & $\begin{array}{c}\text { Vehicle } \\
\text { Performances }\end{array}$ & $\begin{array}{c}\text { Refueling } \\
\text { Infrastructure }\end{array}$ & $\begin{array}{l}\text { Refueling } \\
\text { Time }\end{array}$ & $\begin{array}{l}\text { Fuel } \\
\text { Cost }\end{array}$ & $\begin{array}{c}\text { Fuel } \\
\text { Production }\end{array}$ & $\begin{array}{c}\text { Usage } \\
\text { Intensity }\end{array}$ & $\begin{array}{c}\text { Route } \\
\text { Planning }\end{array}$ \\
\hline $\begin{array}{c}\text { Ramachandran et al., } 2015 \\
\text { [56] }\end{array}$ & & & & $x$ & & & & & $x$ & & \\
\hline Ceraolo et al., 2017 [57] & $\mathrm{x}$ & $\mathrm{x}$ & $\mathrm{x}$ & & $\mathrm{x}$ & & & $x$ & & & \\
\hline Hardman et al., 2013 [58] & $\mathrm{x}$ & & $\mathrm{x}$ & & & $\mathrm{x}$ & & & & & \\
\hline $\begin{array}{c}\text { Maniatopoulus et al., } 2015 \\
\text { [59] }\end{array}$ & & & & $x$ & & $x$ & & $x$ & $x$ & & \\
\hline Jones et al., 2020 [60] & $x$ & $x$ & & & & & & $x$ & & $x$ & \\
\hline Le Duigou et al., 2014 [61] & $x$ & $x$ & & & & & & $x$ & & $x$ & \\
\hline $\begin{array}{c}\text { Number of papers per } \\
\text { attribute }\end{array}$ & 18 & 21 & 25 & 17 & 22 & 10 & 2 & 16 & 8 & 8 & 1 \\
\hline
\end{tabular}




\section{Discussion}

The literature review shows that most of the research works, reports and demonstration projects for urban delivery transport applications focus mainly on battery commercial electric vehicles, instead of fuel cell electric vehicles, inheriting technology from the electric passenger vehicles. Nevertheless, under the actual conditions of fuel price and political trends the EVs are not competitive [7] and other alternative-fuel vehicles (AFVs), as CNG-powered vans, are preferred [37].

Although the use of BEVs in the light-duty segment (parcel distribution and transportation of goods) has already become a reality, with vehicles showing higher electric ranges and providing better levels of fuel efficiency than diesel vans operating in low speed and several stops-and-go driving conditions [31,34], electric vans are having problems to reach positioning and consolidate recognition on the market [53]. The reviewed papers show that the problem has several techno-economic and operational feasibility issues in the use of these types of powertrains in metropolitan areas for delivery activities focused on three stakeholders: fleet operator prospects, electrical energy system issues and environmental concerns. There is a relationship, shown in Table 7, between the stakeholders and the key attributes generated from the analysis of the selected studies that will be discussed in the following sections.

Table 7. Relationship between stakeholders and attributes evaluated in the selected studies.

\begin{tabular}{cccc}
\hline Fleet Operator & $\begin{array}{c}\text { Electrical Energy } \\
\text { System }\end{array}$ & $\begin{array}{c}\text { Environmental } \\
\text { Concerns }\end{array}$ \\
\hline Linked attributes & $\begin{array}{c}\text { Vehicle performances Usage intensity } \\
\text { Refueling features (time and } \\
\text { infrastructure) }\end{array}$ & $\begin{array}{c}\text { Fuel production } \\
\text { efficiency and cost } \\
\text { Supply features }\end{array}$ & $\begin{array}{c}\text { Whole life cycle } \\
\text { environment efficiency }\end{array}$ \\
& $\begin{array}{c}\text { Total cost of ownership (purchase } \\
\text { price and operational costs). }\end{array}$ & \\
\hline
\end{tabular}

\subsection{Fleet Operator Prospects}

As already seen, a lot of logistics operators have investigated the suitability of use AFVs in their daily operations with hard driving conditions and special vehicle requirements, such us payload and driving range among others [37]. So, if EVs want to gain market share in commercial vehicles fulfilling user transport task requirements efficiently, it is important to assess several techno-economic and operational issues that have an important influence in the purchase decision. These issues are namely payload, duty cycle, refueling infrastructure, vehicle performances, maintenance and reliability concerns, and total cost of ownership.

The payload is significantly reduced in battery-electric vans mainly due to the weight of batteries. While a conventional diesel van has a payload of around $1600 \mathrm{~kg}$, a battery-electric van has a much lower capacity. If we take as a reference the Renault Master L1H2 diesel-powered has $1600 \mathrm{~kg}$ of effective load in contrast to $1100 \mathrm{~kg}$ of ZE version with the same $9 \mathrm{~m}^{3}$ of useful volume. This issue cannot be overcome unless the maximum allowed gross vehicle $\mathrm{m}$ would be $4250 \mathrm{~kg}$ [12]. Nevertheless, the payload in vans for urban delivery activities might be a non-issue from a utility point of view [36,54], but it has effects in the energy consumption, vehicle dynamics and powertrain components sizing. The fuel cell powertrains are the least overweight. In FCEVs, hydrogen is stored onboard in high-pressure fuel tanks (70 MPa). Current energy density for hydrogen power systems is at best $1.5 \mathrm{~kW} \mathrm{~h} / \mathrm{kg}$, in contrast, typical Li-Ion batteries offer at most $0.3 \mathrm{~kW} \mathrm{~h} / \mathrm{kg}$ [35]. Typical fuel cell system, including the hydrogen tanks, a high power battery pack for regenerative braking and peak power demand, and the fuel cell stack plus all auxiliary fuel cell system components such as a humidifier, air blowers and control electronics, offer $0.69-1.5 \mathrm{~kW} \mathrm{~h} / \mathrm{kg}$. On the other hand, typical Li-Ion batteries offer (for $100 \% \mathrm{SoC}$ ) $0.2-0.3 \mathrm{~kW} \mathrm{~h} / \mathrm{kg}$ and (for $70 \% \mathrm{SoC}$ ) $0.14-0.24 \mathrm{~kW} \mathrm{~h} / \mathrm{kg}$. Therefore, the same range of a battery-electric vehicle can be achieved with a FCEV with less weight, and hence, with less fuel consumption [42]. 
Another important issue is the duty cycle. There are user requirements, such us route profile (slope), climate conditions, nominal load and driving style that could affect the electric van operational range. The range of the vehicle will limit daily trips [31]. Most of the papers reviewed consider $200 \mathrm{~km}$ as a suitable range for a daily route, but this goal is difficult to achieve with available battery-electric vans in the market. The averaged real range of the battery-electric vans should be around the $80-120 \mathrm{~km}$ range, but in certain work conditions, such as high load, urban driving with frequent stop-and-go, hot or cold days, road profile (slope) and driver behavior, the range should be significantly lower [27,30,62-64]. So, the real range of electric vans is quite different from the official range [37], and this is one of the main problems of BEVs. Battery packs that increase the range up to $200 \mathrm{~km}$ or more could be a solution, but it presents obvious problems of costs and recharging time [24]. An additional problem is the increase in weight and volume, whose impact is noticeable in electric energy consumption and payload [27,30,35]. Nevertheless, the excess weight to gain range in an FCEV is negligible, only larger tanks are needed [42].

Additionally, there are some issues with respect to recharging and refueling infrastructure. The battery-electric vans, due to the limited range, need a suitable recharging infrastructure with high power outlets (more than $20 \mathrm{~kW}$ ) to reduce the recharging time, while recharging time is a critical factor from the user point of view [31]. According to European Alternative Fuels Observatory (EAFO) data, in the EU zone, the quality of charging public stations is increasing, but less than $9.5 \%$ are fast-charging points and the share of electric vehicles per charging point is low on average. Moreover, fast-charging is limited by the onboard vehicle charger capacity, usually around $7 \mathrm{~kW}$, and could origin battery reliability problems reducing the service life. An alternative method to solve the problem is managing delivery routes [28] to avoid idle times needed for recharging. However, firstly it is not a simple matter to determine the most suitable daily delivery path for a vehicle fleet composed of a set of internal combustion, hybrid and full battery electric vehicles. It implies taking into account several, and an interrelated number of parameters, such as constrained driving-range capabilities, traffic jam, weather conditions, driver behavior and route orography, for example. Secondly, there is a recent increase in the frequency of urban deliveries. There has been considerable business development based on urban delivery possibilities and this affects the mileage [30]. Another possible solution is using battery swap stations, but it is difficult to become a reality because of the different battery standards available in the market [31]. The situation is even worse in actual hydrogen refueling stations. Taking into account European Alternative Fuels Observatory (EAFO) data the total number of HRS in the EU-33 zone is 124 , but the future hydrogen infrastructures perspectives and costs associated with hydrogen production in an efficient and environmentally-friendly way are important issues too [8]. Nevertheless, the hydrogen refueling time in a fuel cell electric van is equivalent to a diesel-powered van, giving to the users a similar feeling [31,44].

On the other hand, the van required performance parameters, such as efficiency, driving speed and acceleration, maximum gradeability rate and range are dependent on the powertrain components (i.e., battery size, fuel cell power, hydrogen storage system, the energy managing strategy among others) and vehicle dynamics (i.e., curb weight, rolling and, although to a minor extent due to the low-speed urban driving conditions, the aerodynamic resistance). There is an increasing trend in the proportion of larger and powerful vans in the market because these kinds of vehicles are more useful in terms of load capacity [36,54], but these factors have a great influence in the van efficiency and $\mathrm{CO}_{2}$ emissions. The tank-to-wheel efficiency is a key factor when comparing FCEVs and BEVs powertrain. Typical fuel cell systems efficiencies are around $40-60 \%$ due to energy consumption of system components, however, BEVs have higher efficiency, in the $80-90 \%$ range $[35,40]$. It is also important to take into account particular and complementary performance attributes of fuel cell stack and batteries, such as batteries' quick response and high peak power, and higher energy density of hydrogen fuel tanks [41].

Continuing with aspects related to maintenance and reliability concerns. Both of them are related to the dealer support and the powertrain components. The importance of dealer support is concerning 
to dealer network, the servicing maintenance interval and warranty periods [32,33]. In respect of powertrain components, according to DOE durability targets, the whole fuel cell system applied to automotive applications has to reach a minimum operating life of $5000 \mathrm{~h}$ and 17,000 start/stop cycles, but actual technology is far away from these targets [47], also maintenance and repair costs (spare parts and service interval frequency) are more expensive than diesel and pure electric powertrains [39]. On the other hand, current battery technologies have to solve problems of longevity, it is necessary to overcome 4000 full recharge cycles, self-discharge issues and performances in extreme climate conditions [35].

Furthermore, the total cost of ownership (TCO) and payback period have key influences in the AFVs purchase decision in large commercial fleets $[7,28]$. While the purchase price of a battery-electric van is higher than diesel models, the running costs are already lower thanks to the electricity and maintenance costs, provided that the van covers a minimum annual mileage $[54,60]$. The annual mileage depends on the transport task, and in the BEV case, it is influenced by the vehicle range and the available refueling infrastructure. In fact, yearly mileage, depreciation period of the van, purchase taxes, fuel price and the second-hand value, which depends on powertrain reliability and infrastructure availability, are key parameters in the TCO calculation $[7,32,33,48]$.

At this point, the reviewed studies differ on the boundary conditions and the parameters used for the calculation of ownership cost. This is the case of the battery replacement cost, usable state of battery charge (SoC), energy prices, powertrain components sizing, and energy consumption. The battery replacement cost is usually omitted because it is considered that it will last the entire household period, which may not be true over certain values of annual mileages and depreciation periods [40]. This is contrary to EVs running costs advantage with the use. On the other hand, reducing the useful percentage of SoC to a real value will reduce the range and increase the operating costs [41]. The energy cost estimation is highly dependent on market conditions and electricity production mix, so its value has variations over time. The powertrain components characteristics, which affect acquisition cost to a large extent, have to fulfill a defined vehicle requirements regard to performances, range and load capacity, and optimized to minimize the operating costs [49]. Finally, the energy consumption considered relies on the duty cycle, the powertrain efficiency and the energy management strategy [25].

At least, the studies analyzed show EV should be cost-effective compared to diesel vans in certain scenario spaces defined by the type of duty cycle and cost of ownership [37,38,45]. The break-even point is different for BEVs and FCEVs, and actually more favorable for BEVs due to operating costs (energy price and maintenance costs), higher resale values and lower purchase price. Another fact detected is that many of techno-economic and operational factors are interrelated.

Nevertheless, from a fleet operator perspective, urban transport services require flexibility, high grade of van service readiness and cost-efficient coverage of delivery tasks [30], hence, the main drawbacks of BEVs such us high purchase cost, limited range, lack of suitable charging infrastructure, long recharge times and limited load capacity have been the key barriers for their market feasibility in urban freight transport activities. Moreover, fuel cell powertrain, notwithstanding its particular drawbacks, seems to be the best choice for heavy-duty vehicles [40,42].

\subsection{Electric Energy System Prospects. Energy Production and Supply Issues}

BEVs should overcome the range limitation in the future using advanced battery technologies with higher energy density and supported by a wide fast-charging public infrastructure, but in this case, it will be necessary to take into account those challenges related to electric grid load balancing when a large number of BEVs are recharging at the same time [27]. Intelligent management of charging periods can avoid these problems and allow a right-sizing of the new infrastructure for electricity transportation [40].

As an alternative, if the van uses hydrogen as alternative energy, could be the development of refueling stations with hydrogen produced on-site through electrolyzers and using electricity from renewable energies [29]. In this way, despite the poor efficiency in the electric energy conversion, using 
less electric power installed compared with a fast-charging electric station, it is possible to supply fuel to more vehicles in much less time [28]. The recharging time and power capacity of recharging stations is an important issue [31].

Another advantage of hydrogen as an energy carrier is the possibility to store peaks of electric power generation from renewable sources (wind and solar) using electrolyzers [8,29,59]. In this way, it is guaranteed the electricity supply when the power generation will be based on renewable energy sources, thanks to seasonal hydrogen storage options [44].

It is necessary to keep in mind that it is more efficient using this electricity to charge batteries because of the electrolysis process loses approximately $25 \%$ of the electric energy [42]. This main reason why the electrolysis is only profitable if the electricity used in the process has a very low cost [27]. However, it also possible to obtain hydrogen in a cost-efficient way from natural gas reforming with carbon capture and storage [8,43], meanwhile the green hydrogen production is coming.

The complementary use of electricity and hydrogen have revealed synergies in energy storage and distribution, reducing infrastructure costs [59].

Infrastructure investment for hydrogen refueling stations based on electrolysis technology using electricity from renewable sources will be more expensive than a battery charging infrastructure if the number of electric-powered vehicle fleets are low, but the situation would the reverse if all the light vehicle fleet changes to electric mobility [44].

\subsection{Environmental Concerns}

BEVs and FCEVs are local zero-emissions, they do not produce noises nor pollutant emissions. However, there are upstream emissions during the vehicle manufacturing process, vehicle maintenance and scrapping, and from the energy generation, storage and distribution.

Battery-electric vehicles, due to their high well to wheel efficiency, have better environmental performances (lower global GHG emissions) than FCEV [29,43,45]. Calculating the benefits in emissions of introducing FCEVs is even more uncertain than BEVs, due to the even wider selection of energy pathways available to produce hydrogen than electricity $[45,52,65]$. Consequently, it is also necessary to keep in mind the electricity production mix and the need for conversion of electrical generation from conventional power plants to renewable energy systems $[28,35,43]$. The availability of green hydrogen and high turnout of renewable sources in the electricity production mix is decisive in the environmental competitiveness of fuel cell electric vans [35,40,45,47].

In the case of BEVs, they can get the highest energy economy and achieve a GHG emission reduction if it is possible to know in advance the real work conditions of the van, optimizing the timing of the vehicle charge and the charging components (hardware and software). However, FCEVs can provide greenhouse gas reductions in hard duty conditions, such as daily trips over $200 \mathrm{~km}$ [42,52].

From the manufacturing processes point of view the extensive use of key raw materials, such as cobalt and lithium for batteries and platinum for fuel cell stacks, might become a problem for the deployment of fuel cell and battery powertrain technologies in the future $[28,41]$.

\subsection{Assessment of FC-EREV Powertrain Deployment in Vans for Metropolitan Delivery Tasks}

Taking into account the strengths and limitations of BEVs and FCEVs for delivery activities in metropolitan areas and the powertrain synergies between both technologies, a good solution could be the FC-EREV powertrain [41]. Figure 3 summarizes FCEVs and BEVs advantages and drawbacks in the use of these technologies for light commercial vehicles compiled from the analyzed papers.

In this range extender concept, one of the major advantages lies in the fact that the power of the fuel cell stack may not be required to move the vehicle, and it can be set to operate at its maximum efficiency. However, the battery and the electric traction system must be powerful enough to move the van in driving conditions [23]. 


\begin{tabular}{|c|c|c|c|}
\hline \multicolumn{2}{|c|}{ FCEV } & \multicolumn{2}{|c|}{ BEV } \\
\hline DRAWBACKS & ADVANTAGES & ADVANTAGES & DRAWBACKS \\
\hline Lack of charging infrastructure & Zero tank to wheel emissions & Zero tank to wheel emissions & $\begin{array}{c}\text { Lack of suitable charging } \\
\text { infrastructure }\end{array}$ \\
\hline Very high purchase costs & Public health benefits & Public health benefits & High purchase costs \\
\hline $\begin{array}{l}\text { Availability of raw materials for } \\
\text { key elements manufacturing }\end{array}$ & $\begin{array}{l}\text { Preferential taxation \& Purchase } \\
\text { subsides }\end{array}$ & $\begin{array}{l}\text { Preferential taxation \& Purchase } \\
\text { subsides }\end{array}$ & $\begin{array}{l}\text { Availability of raw materials for } \\
\text { key elements manufacturing }\end{array}$ \\
\hline FC limited service life & $\begin{array}{l}\text { Improved driving experience in } \\
\text { urban environments }\end{array}$ & $\begin{array}{l}\text { Improved driving experience in } \\
\text { urban environments }\end{array}$ & $\begin{array}{c}\text { Battery limited service life (fast } \\
\text { charging) }\end{array}$ \\
\hline $\begin{array}{c}\text { Poor WtW energy efficiency (via } \\
\text { electrolysis) }\end{array}$ & $\begin{array}{l}\text { Reduction of dependency on } \\
\text { fossil fuels increasing the use of } \\
\text { local energy resources }\end{array}$ & $\begin{array}{l}\text { Reduction of dependency on } \\
\text { fossil fuels increasing the use of } \\
\text { local energy resources }\end{array}$ & $\begin{array}{l}\text { Limited driving range \& High } \\
\text { recharge time }\end{array}$ \\
\hline $\begin{array}{l}\text { Fuel-cell's poor dynamic } \\
\text { response }\end{array}$ & $\begin{array}{l}\text { Equivalent driving range to } \\
\text { conventional vans \& Short } \\
\text { refuelling time }\end{array}$ & $\begin{array}{l}\text { Low operating costs (fuel, repair } \\
\text { and maintenance costs) }\end{array}$ & $\begin{array}{l}\text { Performances at high and low } \\
\text { temperatures }\end{array}$ \\
\hline $\begin{array}{l}\text { Operating cost ( } \mathrm{H} 2 \text { fuel, repair } \\
\text { and maintenance costs) }\end{array}$ & High energy density ${ }^{(2)}$ & High power density of batteries & Low energy density of batteries (3) \\
\hline Long term reliability & $\begin{array}{c}\text { No changes in consumer } \\
\text { behaviour }\end{array}$ & Mature technology $\left(\operatorname{TRL}^{(1)} 8-9\right)$ & Limited payload capacity \\
\hline $\begin{array}{l}\text { Developing technology (TRL }{ }^{(1)} \\
6-7), \text { no commercial vehicles } \\
\text { available }\end{array}$ & & High energy efficiency & $\begin{array}{l}\text { Limited vehicle applications (light } \\
\text { duty in urban areas) }\end{array}$ \\
\hline $\begin{array}{l}\text { Complex powertrain } \\
\text { arquitectures }\end{array}$ & & Scalable existing infrastructure & \\
\hline
\end{tabular}

Figure 3. Advantages and drawbacks for BEVs and FCEVs in light commercial vehicles. ${ }^{1}$ Technology readiness levels (TRL), available levels 1 to 9 (maximum). Diesel technology has TRL 9. ${ }^{2}$ Hydrogen fuel has $33.3 \mathrm{~kW} \mathrm{~h} / \mathrm{kg}_{\mathrm{H} 2}$ and fuel cell system offer $0.69-1.5 \mathrm{~kW} \mathrm{~h} / \mathrm{kg}_{\mathrm{FC} \text { system }}{ }^{3}$ Typical Li-Ion batteries system offer for $70 \%$ SoC $0.14-0.24 \mathrm{~kW} \mathrm{~h} / \mathrm{kg}_{\text {Bsystem }}$.

The traction battery can efficiently cover short distances (up to $100 \mathrm{~km}$ ) and guarantee peak power demands, while the fuel cell stack allows fast refueling and sufficient range for long distances $[28,30,34,38,41,46]$.

As previously mentioned, the total cost of ownership is the key factor in the decision to purchase. The purchase price for an FC-EREV van will be cheaper than an FCEV but more expensive than a $\mathrm{BEV}$, but with less range. An analysis of operational costs [30] shows the benefits for the hybrid electrified powertrains compared with conventional vans, but the running cost is highly affected by the hydrogen cost, maintenance expenses, vehicle lifetime and annual mileage [25,32,48]. Some of these factors rely on the right powertrain component sizing. The cost-efficient component sizing depends on onboard hydrogen storage capacity, fuel cell power and traction battery size, while maintaining the performances [49,61].

On the other hand, and taking into account maintenance and repair aspects, in vehicles equipped with a proton exchange membrane (PEM) fuel cell stack type, short driving distance causes membrane stress reducing the estimated service life. In contrast, a PEM fuel cell stack working in stationary conditions can reach up to $40,000 \mathrm{~h}$ of service. Additionally, the Li-ion batteries for vehicles have an operative life of less than 4000 deep discharge cycles and a service life around 10-15 years. However, the battery state of health and lifecycles can vary as a function of the depth of the charge (DoD), discharge process (high or low) and the type of recharge selected (normal or fast). That is why a battery and fuel cell working together in an FC-EREV in urban driving conditions can improve both the reliability and performance, of the commercial vehicles, using the fuel cell working at its maximum 
efficiency to assist the battery in order to maintain a determined state of charge (SoC) level, improving the range and the overall battery and fuel cell life, and in the same way reducing the operating costs $[23,34,46]$. Consequently, it is important to have adequate energy management combining both power sources [47].

From a performance point of view, the van configuration in terms of useful volume and payload versus range is better for FC-EREV powertrain because the overweight to increase the range depends on hydrogen tanks, while in BEVs, mass increase significantly with the range due to the heavier batteries, chassis stiffness and oversized powertrain components (brakes and traction motor, among others) in order to keep the same performance [34,42]. Current technology states the useful energy density for the FCEV powertrain with $70 \mathrm{MPa}$ pressure storage tanks reaches ranges almost four times higher than an equivalent BEV [42]. In this way, FC-EREV configuration gives the option to optimize the whole system to achieve higher cost-effectiveness than either which FCEV or BEV can offer [35,38]. The estimated lifecycle cost of FC-EREVs and BEVs would be similar, depending on daily mileage and costs estimations for electricity generation and hydrogen fuel. Nevertheless, the low operating cost of BEVs allows them to stay competitive when the driving range is under $100 \mathrm{~km}$, but if overall costs are taken care of, FC-EREV represents a better option [41,48].

The efficiency of FC-EREVs should be similar to those provided by BEVs (over 70\%) in short distances or FCEVs on large trips (around 50\%) [35]. However, FC-EREV powertrain components sizing becomes complicated, a particular range requirement could be satisfied using several different hardware configurations depending on cost-effectiveness and required performances for the singular transport activity. In electric hybrid powertrains, a blended battery energy management strategy is used, based on different shares of two main operating strategies; charge depleting (CD) and charge sustaining (CS) operation mode [30]. An FC-EREV uses a blended battery energy management where the vehicle drives initially in CD mode and once the battery has reached a predefined SoC threshold, the fuel cell turns on to empower the battery allowing slow down battery discharge. The definition of the share in each mode according to technical, economical or environmental rules determine the right sizing of the powertrain components and energy management strategy, in order to maximize the energy efficiency of the powertrain configuration and minimize costs $[32,38,52]$, maximizing the use of, up to now, inexpensive off-board electricity, while the driving range is limited only by the amount of hydrogen stored in the fuel tanks $[24,38,46,48,53]$. Nevertheless, determine the degree of hybridization ratio $(\mathrm{DOH})$, it expresses the ratio between the peak power of the battery relative to the whole powertrain power, and the operational strategy in CD or CS mode in an extended range is not an easy matter.

It is important to remark that FC-EREV powertrain technology opens the opportunity to upgrade the existing battery-powered vans with a fuel cell range extender system. In this way, the fleet operators have the option to address delivery activities with large range requirements in metropolitan areas [39]. The lack of public hydrogen infrastructure becomes a minor matter because several delivery trips could be covered with electricity without range anxiety [44]. However, there already exists an electricity net infrastructure and, in the short term, building a recharging infrastructure over the existing power grid is likely to be significantly easier and less expensive than building a hydrogen refueling station [41]. However, this type of powertrain encourages a complementary combination of the electric charging and the hydrogen refueling infrastructure and will help to maximize energy efficiency, optimizing the use of renewable energy sources [44].

Nevertheless, there are several issues for the deployment of FC-EREV powertrains in light-duty commercial vehicles related to market status and refueling infrastructure. Nowdays, there is no flexibility for vehicle selection. Current commercial vehicle availability is limited to custom-made range-extended battery electric vehicles or prototypes. For further market deployment, more development of FC-EREV delivery van prototypes and increase the number of successful demonstration projects will be necessary [39]. On the other hand, the hydrogen refueling infrastructure available is 
very low, so the best solution should be the use of HRS sited at the logistic operator vehicle depot using stand-alone hydrogen generators.

Everything points to the best choice for the future development of FCEV technology begining with the deployment of FC-EREV [41].

\section{Conclusions}

This paper provides an overview of the literature addressing the employment of FC-EREV powertrain for light-duty vehicles in UFT services. It puts the focus firstly on the hydrogen fuel cell stack system that works as a range extender (FC-EREV) for a battery-powered N1 class type van designed for the transportation and delivery of goods. A literature review is conducted to assess the feasibility of using the hydrogen fuel cell range extender technology in commercial electric battery vans and provide insights into the key factors and issues for sizing the powertrain components and power management strategies to meet metropolitan freight fleet needs.

The review has explored and analyzed literature which involves three main aspects: research topic, powertrain configuration and approach or method used. The data analysis reveals that the selected documents have focused mainly on five topics. The five topics are: cost, performance and efficiency analysis, market potential (feasibility), environmental perspectives, powertrain components sizing and related technical features, and refueling infrastructure issues. These topics are classified into three areas: economic, technical and operational. These techno-economic and operational issues are of particular interest to give an answer to main stakeholders involved, such as fleet operators, energy system prospects and environmental concerns. Each issue shows specific attributes:

- Economic attributes: purchase price and operational costs.

- Technological attributes: range, environmental efficiency and vehicle performances.

- Operational attributes: refueling infrastructure, refueling time, fuel cost, fuel production, usage intensity and route planning.

Besides, by observing the number of articles per attribute, the attention is mainly focused on the cost, range, vehicle performance and efficiency analysis of electric powertrains in the UFT area. According to the research, topic key attributes to ensure the widespread use of using hydrogen-based ECVs in UFT are, in order of importance, the total cost of ownership (purchase prices and operational costs), operational conditions (range and usage intensity), vehicle performances (payload), environmental efficiency (pollutant emissions), fuel production and supply characteristics (cost) and refueling features (time and infrastructure).

On the other hand, several of the studies analyzed focuses on the comparison of BEV and FCEV powertrains for UFT activities and less attention is paid to hybrid electric powertrains in light-duty commercial vehicles, such us FC-EREV or FC-PHEV. Furthermore, the selected studies have conducted research work on the problem, using mainly modeling and simulation techniques with several powertrain configurations and energy managing strategies are used to study fuel efficiency, costs, emissions and charging infrastructure needs.

As a result of the investigation, assessment of the suitability of hydrogen fuel cell range extender powertrain in light-duty commercial vehicles for metropolitan delivery tasks are conducted, taking into account the strengths and limitations of BEVs and FCEVs for delivery activities in metropolitan areas and the powertrain synergies between both technologies. In this sense, the main findings of the study are:

- User requirements for light-duty vans are related to the total cost of ownership (purchase and operating costs), autonomy between refueling (range), performance (payload, maximum gradeability rate, top speed, acceleration, etc.), operating time per day, flexibility to assign a delivery route, uptime (reliability and service maintenance intervals) and service life. 
- Refueling infrastructure is a key issue for BEV and FCEV technologies. Nowdays, the number of available electric public recharging stations, although fast-growing, are limited. The situation is even worse in actual hydrogen refueling stations.

- FC-EREV van purchase price is strongly influenced by the sizing of the powertrain components used and its costs over time. Different hardware configurations and energy management strategies adapted to particular duty conditions (range over $200 \mathrm{~km}$ and/or high usage intensity working conditions) could lead to a cost-effectiveness configuration.

- FC-EREV van operational costs depend on the distance traveled per year, the number of years of ownership, maintenance expenses, the fuel cost (electricity and hydrogen) and the proportion of each energy used, this last factor is influenced by duty cycle conditions, the degree of hybridization ratio, the energy management strategy and the range available with electricity and hydrogen. The current fuel cost, to a larger extent the hydrogen cost, and the high maintenance expenses, because of greater technical complexity than $\mathrm{BEV}$, could lead to a longer ownership period and it could reduce the final second-hand resale price.

- FC-EREV van has clear advantages when the averaged real range needed is more than $200 \mathrm{~km}$ and/or high usage intensity conditions that could affect the energy consumption, as route profile (steep slopes), high load, high traffic density, delivery plan with frequent stop-and-go, adverse ambient conditions (hot or cold days) and aggressive driving style.

- FC-EREV van powertrain and energy management strategy flexibility configuration allows to fulfill a great variety of user-defined performance parameters, such as range, payload, driving speed and maximum gradeability rate, with fewer effects on fuel consumption and vehicle dynamics in hard-duty conditions. Powertrain configuration and energy management strategies have a strong influence on fuel efficiency.

- The hydrogen refueling time in an FC-EREV van is equivalent to a diesel-powered van, giving a similar feeling to the users. The electricity recharging time depends on the recharging infrastructure power outlet and the onboard vehicle charger capacity.

- FC-EREV van environmental performances are more uncertain than BEVs due to variable powertrain configuration, the wider selection of energy pathways available to produce hydrogen than electricity and the current FC technology readiness, but FC-EREV vans could provide advantageous life cycle GHG reduction in hard duty conditions and/or daily trips over $200 \mathrm{~km}$. In any case, as BEVs, depends on the use of renewable energy sources.

Moreover, key factors for sizing the powertrain components to meet metropolitan freight carrier needs are identified. The degree of hybridization, that is to say, how the powertrain components should be designed to operate in blended or all-electric mode and the energy management strategies are the most significant drivers. These factors influence the sizing of the powertrain components once the vehicle performance requirements have been met.

At present, FC-EREV inherits the most advantages of both technologies overcoming range and vehicle performance limitations, but also some of the weaknesses, such as lack of suitable charging infrastructure, high purchase cost, faces high technical risks and the lack of flexibility for vehicle selection. However, FC-EREV configuration gives the option to optimize the efficiency of the whole system to reach low operational costs, opens the opportunity for fleet operators to upgrade of existing battery-powered vans with a fuel cell range extender, offers an alternative path to GHG reduction and petroleum dependence, give more relaxed requirements for refueling infrastructures, less range anxiety and refueling idle times.

The authors of this literature review work have tried to shed light on the emerging problems that suppose the selection of the more suitable powertrains used in the currently diffuse last-mile delivery scenario trough a better knowledge of hydrogen fuel cell range extender van attributes and the way to satisfactorily match these attributes with end-user preferences in urban delivery tasks. For future research it is worth paying attention to (1) the influence of user requirements on the powertrain and 
the energy management strategy configuration, (2) how sensitive is the energy consumption and cost to these factors?, (3) which energy management strategy is adequate to maximize the efficiency for FC-EREV powertrains in metropolitan delivery activities and, finally, (4) challenges on refueling infrastructure facilities.

Author Contributions: Conceptualization, O.C. and R.Á.; methodology, O.C. and R.Á.; validation, O.C., R.Á. and R.D.; formal analysis, O.C., R.Á. and R.D.; writing—original draft preparation, O.C.; writing—review and editing, O.C., R.Á. and R.D.; supervision, R.Á. and R.D. All authors have read and agreed to the published version of the manuscript.

Funding: This research received no external funding.

Conflicts of Interest: The authors declare no conflict of interest.

\section{Abbreviations}

$\begin{array}{ll}\text { AFP } & \text { Alternative Fuels and Powertrains } \\ \text { AFV } & \text { Alternative Fuel Vehicle } \\ \text { BEV } & \text { Battery Electric Vehicle } \\ \text { B2C } & \text { Business to Costumer } \\ \text { CADC } & \text { Common Artemis Driving Cycles } \\ \text { CD } & \text { Battery Charge Depleting mode } \\ \text { CS } & \text { Battery Charge Sustaining mode } \\ \text { DoD } & \text { Battery Depth of Discharge } \\ \text { DOE } & \text { US Department of Energy } \\ \text { DoH } & \text { Degree of Hybridization } \\ \text { ECV } & \text { Electric Commercial Vehicle } \\ \text { EFV } & \text { Electric Freight Vehicles } \\ \text { EREV } & \text { Extended Range Electric Vehicle } \\ \text { EU } & \text { European Union } \\ \text { FCEV } & \text { Fuel Cell Electric Vehicle } \\ \text { FC-EREV } & \text { Fuel Cell Extended Range Electric Vehicle } \\ \text { FC-PHEV } & \text { Fuel Cell Plug-in Hybrid Electric Vehicle } \\ \text { HEV } & \text { Hybrid Electric Vehicle } \\ \text { HRS } & \text { Hydrogen Refueling Station } \\ \text { GHG } & \text { Greenhouse Gas Emissions } \\ \text { GVM } & \text { Gross Vehicle Mass rating } \\ \text { ICE } & \text { Internal Combustion Engine } \\ \text { LCA } & \text { Life Cycle Assessment } \\ \text { LCV } & \text { Light Commercial Vehicle } \\ \text { LDV } & \text { Light-Duty Vehicle } \\ \text { NEDC } & \text { New European Driving Cycle } \\ \text { PCU } & \text { Power Control Unit } \\ \text { PEM } & \text { Proton-Exchange Membrane } \\ \text { PHEV } & \text { Plug-in Hybrid Electric Vehicle } \\ \text { UDC } & \text { Urban Delivery Cycle } \\ \text { US } & \text { United States } \\ \text { SoC } & \text { Battery State of Charge } \\ \text { TCO } & \text { Total Cost of Ownership } \\ \text { TtW } & \text { Tank to Wheel } \\ \text { WHVC } & \text { World Harmonized Vehicle Cycle } \\ \text { WtW } & \text { Well to Wheel } \\ & \end{array}$




\section{Appendix A}

Table A1. Keywords and search strings considered in the literature review.

\begin{tabular}{|c|c|c|c|}
\hline Keywords & \multicolumn{3}{|c|}{ Hydrogen, van, freight, logistics, delivery, urban, city, sustainable } \\
\hline Combined Terms & \multicolumn{3}{|c|}{$\begin{array}{c}\text { Fuel cell, Hydrogen range extender, Urban freight, City logistics, Last-mile delivery, } \\
\text { Delivery van, Light commercial vehicles, Medium duty vehicles, Sustainable Logistics, } \\
\text { Sustainable supply chain }\end{array}$} \\
\hline B1 & Light commercial vehicles & AND & Fuel cell \\
\hline B2 & Urban freight & AND & Fuel cell \\
\hline B3 & Sustainable supply chain & AND & Fuel cell \\
\hline B4 & Medium duty vehicles & AND & Fuel cell \\
\hline B5 & City logistics & AND & Fuel cell \\
\hline B6 & Delivery van & AND & Fuel cell \\
\hline B7 & Urban logistics & AND & Fuel cell \\
\hline B8 & Last-mile delivery & AND & Fuel cell \\
\hline B9 & Sustainable logistics & AND & Fuel cell \\
\hline B10 & Delivery van & AND & Hydrogen Range Extender \\
\hline B11 & Light commercial vehicles & AND & Hydrogen Range Extender \\
\hline B12 & Last-mile delivery & AND & Hydrogen Range Extender \\
\hline
\end{tabular}

\section{Appendix B}

Table A2. Inclusion criteria and dimensions considered.

\begin{tabular}{cc}
\hline Number of Selected Documents for Analysis & $\begin{array}{c}\text { Summary of Dimensions Considered as Inclusion Criteria } \\
\text { Market feasibility, Environmental concerns, charging } \\
\text { infrastructures issues, economic aspects or technical features } \\
\text { of FC-EREV technologies in light and light/medium duty } \\
\text { vehicles for urban delivery tasks }\end{array}$ \\
$\begin{array}{c}\text { Comparison between FCEV and BEV technologies in light } \\
\text { and light/medium duty vehicles for urban delivery tasks }\end{array}$ \\
\hline
\end{tabular}

Appendix C

Table A3. Overview of selected studies.

\begin{tabular}{|c|c|c|c|c|c|}
\hline Authors (Ref., Year) & Publisher-Journal & $\begin{array}{l}\text { SJR } \\
2019\end{array}$ & $\begin{array}{l}\text { Document } \\
\text { Type }\end{array}$ & Country & $\begin{array}{l}\text { Vehicle } \\
\text { Type }\end{array}$ \\
\hline $\begin{array}{l}\text { Adebusuyi et al., } \\
2012 \text { [27] }\end{array}$ & $\begin{array}{l}\text { IEE-Electrical Systems for } \\
\text { Aircraft, Railway and Ship } \\
\text { Propulsion }\end{array}$ & NAQ & $\begin{array}{c}\text { Conference } \\
\text { paper }\end{array}$ & Denmark & PC \& CV \\
\hline $\begin{array}{l}\text { Arnhold et al., } 2017 \\
\text { [28] }\end{array}$ & $\begin{array}{l}\text { Springer-ATZ Elektronik } \\
\text { worldwide }\end{array}$ & 0.19 & Journal article & Germany & PC \& CV \\
\hline $\begin{array}{c}\text { Bartolozzi et al., } 2013 \\
\text { [29] }\end{array}$ & Elsevier-Applied energy & 3.61 & Article & Italy & $\mathrm{CV}$ \\
\hline $\begin{array}{c}\text { Bergmann et al., } 2017 \\
\text { [30] }\end{array}$ & $\begin{array}{l}\text { Springer-Internationaler } \\
\text { Motorenkongress }\end{array}$ & NAQ & $\begin{array}{l}\text { Conference } \\
\text { paper }\end{array}$ & Germany & $\mathrm{CV}$ \\
\hline Juan et al., 2016 [31] & MDPI-Energies & 0.64 & Article & Spain & $\mathrm{CV}$ \\
\hline $\begin{array}{l}\text { Kleiner et al., 2017a } \\
\text { [7] }\end{array}$ & $\begin{array}{l}\text { EVS-30th International } \\
\text { Electric Vehicle Symposium }\end{array}$ & NAQ & $\begin{array}{l}\text { Conference } \\
\text { paper }\end{array}$ & Germany & $\mathrm{CV}$ \\
\hline $\begin{array}{c}\text { Kleiner et al., } 2017 \mathrm{~b} \\
{[32]}\end{array}$ & $\begin{array}{l}\text { EVS-30th International } \\
\text { Electric Vehicle Symposium }\end{array}$ & NAQ & $\begin{array}{l}\text { Conference } \\
\text { paper }\end{array}$ & Germany & $\mathrm{CV}$ \\
\hline $\begin{array}{l}\text { Kleiner et al., } 2015 \\
\text { [33] }\end{array}$ & $\begin{array}{l}\text { EVS-28th International } \\
\text { Electric Vehicle Symposium }\end{array}$ & NAQ & $\begin{array}{l}\text { Conference } \\
\text { paper }\end{array}$ & Germany & $\mathrm{CV}$ \\
\hline Millo et al., 2016 [34] & $\begin{array}{l}\text { Elsevier-International } \\
\text { Journal of Hydrogen Energy }\end{array}$ & 1,14 & Article & Italy & $\mathrm{CV}$ \\
\hline
\end{tabular}


Table A3. Cont.

\begin{tabular}{|c|c|c|c|c|c|}
\hline Authors (Ref., Year) & Publisher-Journal & $\begin{array}{l}\text { SJR } \\
2019\end{array}$ & $\begin{array}{l}\text { Document } \\
\text { Type }\end{array}$ & Country & $\begin{array}{l}\text { Vehicle } \\
\text { Type }\end{array}$ \\
\hline $\begin{array}{l}\text { Ntziachristos et al., } \\
2012[35]\end{array}$ & $\begin{array}{l}\text { Publications Office of the } \\
\text { EU-JRC Scientific and } \\
\text { Policy Reports } \\
\text { EEVC-2015 European }\end{array}$ & NI & Report & Italy & PC and CV \\
\hline $\begin{array}{c}\text { Özdemir et al., } 2015 \\
{[36]}\end{array}$ & $\begin{array}{c}\text { Battery, Hybrid and Fuel } \\
\text { Cell Electric Vehicle } \\
\text { Congress }\end{array}$ & NI & $\begin{array}{l}\text { Conference } \\
\text { paper }\end{array}$ & Germany & $\mathrm{PC}$ and $\mathrm{CV}$ \\
\hline $\begin{array}{c}\text { Propfe et al., } 2011 \\
{[37]}\end{array}$ & $\begin{array}{l}\text { EEVC-2011 European } \\
\text { Electric Vehicle Congress }\end{array}$ & NI & $\begin{array}{l}\text { Conference } \\
\text { paper }\end{array}$ & Germany & $\mathrm{CV}$ \\
\hline Wood et al., 2013 [38] & $\begin{array}{c}\text { SAE_-2013 Commercial } \\
\text { Vehicle Engineering } \\
\text { Congress }\end{array}$ & 0.38 & $\begin{array}{l}\text { Conference } \\
\text { paper }\end{array}$ & US & $\mathrm{CV}$ \\
\hline Ruf et al., 2017 [39] & $\begin{array}{c}\text { Fuel Cells and Hydrogen } 2 \\
\text { Joint Undertaking (FCH2JU) } \\
-\mathrm{N}^{\circ} \text { FCH/OP/contract 180, } \\
\text { Reference Number FCH } \\
\text { JU2017 D4259 }\end{array}$ & NI & Report & US & $\mathrm{CV}$ \\
\hline $\begin{array}{l}\text { Van Mierlo et al., } \\
2006 \text { [40] }\end{array}$ & $\begin{array}{c}\text { Elsevier-Energy } \\
\text { Conversion and } \\
\text { Management }\end{array}$ & 2.92 & Journal article & Belgium & PC and CV \\
\hline Offer et al., 2010 [41] & Elsevier-Energy Policy & 2.17 & Journal article & UK & $\mathrm{PC}$ and $\mathrm{CV}$ \\
\hline Thomas, 2009 [42] & $\begin{array}{l}\text { Elsevier-International } \\
\text { Journal of Hydrogen Energy }\end{array}$ & 1.14 & Journal article & US & PC and CV \\
\hline Thomas, 2009 [43] & $\begin{array}{c}\text { Elsevier-International } \\
\text { Journal of Hydrogen Energy }\end{array}$ & 1.14 & Journal article & US & PC and CV \\
\hline $\begin{array}{l}\text { Kelouwani et al., } \\
2013 \text { [23] }\end{array}$ & $\begin{array}{c}\text { Elsevier-Journal of Power } \\
\text { Sources }\end{array}$ & 2.11 & Journal article & Canada & $\mathrm{PC}$ and $\mathrm{CV}$ \\
\hline $\begin{array}{c}\text { Robinius et al., } 2018 \\
\text { [44] }\end{array}$ & $\begin{array}{c}\text { TU Wien Energy and } \\
\text { Environment Research } \\
\text { Centre }\end{array}$ & 13.02 & Report & Germany & PC and CV \\
\hline $\begin{array}{c}\text { Baptista et al., 2010b } \\
\text { [45] }\end{array}$ & $\begin{array}{l}\text { Elsevier-International } \\
\text { Journal of Hydrogen Energy }\end{array}$ & 1.14 & Journal article & Portugal & $\mathrm{PC}$ and $\mathrm{CV}$ \\
\hline $\begin{array}{c}\text { Jensen et al., } 2013 \\
\text { [46] }\end{array}$ & $\begin{array}{l}\text { IEEE_-Transactions on } \\
\text { Vehicular Technology }\end{array}$ & 1.63 & Journal article & Denmark & PC and CV \\
\hline $\begin{array}{c}\text { Kromer and } \\
\text { Heywood, } 2007 \text { [47] }\end{array}$ & $\begin{array}{l}\text { MIT_Sloan Automotive } \\
\text { Laboratory }\end{array}$ & NI & Report & US & PC and CV \\
\hline $\begin{array}{c}\text { Sharer et al., } 2013 \\
\text { [48] }\end{array}$ & $\begin{array}{l}\text { MDPI-World Electric } \\
\text { Vehicle Journal }\end{array}$ & 0.19 & Journal article & US & $\mathrm{CV}$ \\
\hline Jokela et al., 2019 [25] & SAE & 0.32 & $\begin{array}{l}\text { Conference } \\
\text { paper }\end{array}$ & UK & $\mathrm{CV}$ \\
\hline Sim et al., 2019 [49] & MDPI-Energies & 0.64 & Journal article & EEUU & $\mathrm{CV}$ \\
\hline $\begin{array}{c}\text { Walters et al., } 2015 \\
{[24]}\end{array}$ & $\begin{array}{l}\text { Electrical Systems for } \\
\text { Aircraft, Railway and Ship } \\
\text { Propulsion (ESARS) }\end{array}$ & NAQ & $\begin{array}{l}\text { Conference } \\
\text { paper }\end{array}$ & Germany & PC \\
\hline $\begin{array}{l}\text { Fernández et al., } \\
2016 \text { [17] }\end{array}$ & $\begin{array}{l}\text { Elsevier-International } \\
\text { Journal of Hydrogen Energy }\end{array}$ & 1.14 & Article & Spain & PC \\
\hline Wu et al., 2019 [50] & $\begin{array}{l}\text { MDPI_World Electric } \\
\text { Vehicle Journal }\end{array}$ & 0.19 & Article & UK & PC \\
\hline $\begin{array}{l}\text { Bendjedia et al., } 2018 \\
\text { [51] }\end{array}$ & $\begin{array}{l}\text { Elsevier-International } \\
\text { Journal of Hydrogen Energy }\end{array}$ & 1.14 & Article & France & PC \\
\hline $\begin{array}{c}\text { Baptista et al., 2010a } \\
\text { [52] }\end{array}$ & $\begin{array}{l}\text { MDPI_World Electric } \\
\text { Vehicle Journal }\end{array}$ & 0.19 & Article & Portugal & PC \\
\hline $\begin{array}{c}\text { Álvarez et al., } 2018 \\
\text { [53] }\end{array}$ & $\begin{array}{c}\text { Springer-Nanostructured } \\
\text { Materials for } \\
\text { Next-Generation Energy } \\
\text { Storage and Conversion: } \\
\text { Fuel Cells }\end{array}$ & NI & Book Section & Spain & PC \\
\hline
\end{tabular}


Table A3. Cont.

\begin{tabular}{|c|c|c|c|c|c|}
\hline Authors (Ref., Year) & Publisher-Journal & $\begin{array}{l}\text { SJR } \\
2019\end{array}$ & $\begin{array}{l}\text { Document } \\
\text { Type }\end{array}$ & Country & $\begin{array}{l}\text { Vehicle } \\
\text { Type }\end{array}$ \\
\hline $\begin{array}{l}\text { Browne et al., } 2014 \\
\text { [54] }\end{array}$ & $\begin{array}{l}\text { Elsevier-Procedia Social } \\
\text { and Behavioral Sciences }\end{array}$ & NAQ & $\begin{array}{l}\text { Conference } \\
\text { paper }\end{array}$ & UK & $\mathrm{CV}$ \\
\hline Lewis et al., 2017 [55] & $\begin{array}{l}\text { IEEE-Transportation and } \\
\text { Electrification Conference } \\
\text { and Expo (ITEC 2017) }\end{array}$ & 0.29 & $\begin{array}{l}\text { Conference } \\
\text { paper }\end{array}$ & US & $\mathrm{CV}$ \\
\hline $\begin{array}{l}\text { Steenberghen et al., } \\
2008[8]\end{array}$ & $\begin{array}{l}\text { Elsevier-Journal of Cleaner } \\
\text { Production }\end{array}$ & 1.89 & Journal article & Belgium & PC and CV \\
\hline $\begin{array}{l}\text { Ramachandran and } \\
\text { Stimming, } 2015 \text { [56] }\end{array}$ & $\begin{array}{l}\text { RSC_Energy and } \\
\text { Environmental Science } \\
\text { IEEE_-International }\end{array}$ & 13.02 & Journal article & US & PC and CV \\
\hline $\begin{array}{c}\text { Ceraolo et al., } 2017 \\
\text { [57] }\end{array}$ & $\begin{array}{l}\text { Conference of Electrical and } \\
\text { Electronic Technologies for } \\
\text { Automotive (AEIT 2017) }\end{array}$ & $\mathrm{NI}$ & $\begin{array}{l}\text { Conference } \\
\text { paper }\end{array}$ & Italy & $\mathrm{CV}$ \\
\hline $\begin{array}{l}\text { Hardman et al., } 2013 \\
\text { [58] }\end{array}$ & $\begin{array}{l}\text { Elsevier-International } \\
\text { Journal of Hydrogen Energy }\end{array}$ & 1.14 & Journal article & UK & PC and CV \\
\hline $\begin{array}{l}\text { Maniatopoulos et al., } \\
2015 \text { [59] }\end{array}$ & $\begin{array}{l}\text { Elsevier-Renewable and } \\
\text { Sustainable Energy Reviews }\end{array}$ & 3.63 & Journal article & Australia & PC and CV \\
\hline Jones et al., 2020 [60] & $\begin{array}{l}\text { Elsevier-Renewable and } \\
\text { Sustainable Energy Reviews }\end{array}$ & 3.63 & Journal article & UK & $\mathrm{CV}$ \\
\hline $\begin{array}{l}\text { Le Duigou and } \\
\text { Smatti, } 2014 \text { [61] }\end{array}$ & $\begin{array}{l}\text { Elsevier-International } \\
\text { Journal of Hydrogen Energy }\end{array}$ & 1.14 & $\begin{array}{l}\text { Conference } \\
\text { paper }\end{array}$ & France & PC \\
\hline
\end{tabular}

Not yet assigned quartile (NAQ). Unranked journal (NI). Commercial vehicle (CV). Passenger vehicle (PC).

\section{Appendix D}

Table A4. Research challenges and problems addressed of studies focused on cost, performance and efficient analysis.

\begin{tabular}{|c|c|c|}
\hline Authors & Problem Addressed & Research Challenge \\
\hline $\begin{array}{l}\text { Adebusuyi et } \\
\text { al., } 2012 \text { [27] }\end{array}$ & $\begin{array}{l}\text { Comparison of three types of vehicle } \\
\text { hybridization powertrains reviewing the actual } \\
\text { running costs using as a basis the NEDC city } \\
\text { cycle. }\end{array}$ & $\begin{array}{l}\text { Running cost; Plug-in hybrid FCEV; } \\
\text { Light commercial vehicles }\end{array}$ \\
\hline $\begin{array}{l}\text { Bergmann et al., } \\
\quad 2017 \text { [30] }\end{array}$ & $\begin{array}{l}\text { Definition of the electric traction motor power, } \\
\text { battery capacity and FCEV range extender } \\
\text { configuration for medium-duty electrical } \\
\text { distribution vehicles based on typical } \\
\text { requirements for a distribution vehicle and } \\
\text { analysis of operation costs. }\end{array}$ & $\begin{array}{l}\text { Medium-duty electrical distribution } \\
\text { vehicles; Load profiles; Powertrain } \\
\text { sizing; Daily mileage; FCEV range } \\
\text { extender configurations; Energy } \\
\text { consumption; Operation cost; Prices } \\
\text { for energy; Urban Delivery Cycle } \\
\text { (UDC) }\end{array}$ \\
\hline $\begin{array}{l}\text { Kleiner et al., } \\
\text { 2017b [32] }\end{array}$ & $\begin{array}{c}\text { Analysis of maintenance and repair costs and } \\
\text { resale value for different alternative commercial } \\
\text { vehicle powertrains. }\end{array}$ & $\begin{array}{l}\text { Electric vehicle; Freight transport; } \\
\text { LCC (Life Cycle Cost) }\end{array}$ \\
\hline $\begin{array}{l}\text { Kleiner et al., } \\
2015 \text { [33] }\end{array}$ & $\begin{array}{l}\text { Techno-economic assessment of electric vehicle } \\
\text { configurations focused on light commercial } \\
\text { vehicles based on a total cost model. }\end{array}$ & $\begin{array}{l}\text { Alternative powertrains; Battery } \\
\text { electric vehicle; Fuel cell electric } \\
\text { vehicle; Light duty commercial vehicle } \\
\text { (N1); Total cost of ownership }\end{array}$ \\
\hline $\begin{array}{l}\text { Ntziachristos } \\
\text { and Panagiota, } \\
2012[35]\end{array}$ & $\begin{array}{c}\text { Evaluation of alternative fuelled powertrains } \\
\text { based on energy efficiency, GHG and AP } \\
\text { emissions, infrastructure and costs criteria, using } \\
\text { information from published studies, and } \\
\text { engineering assessments. }\end{array}$ & $\begin{array}{l}\text { Greenhouse gas (GHG); Electric and } \\
\text { hybrid vehicle; Energy efficiency; } \\
\text { Energy security; Air Pollutants (AP); } \\
\text { Infrastructure; Costs }\end{array}$ \\
\hline
\end{tabular}


Table A4. Cont.

\begin{tabular}{|c|c|c|}
\hline Authors & Problem Addressed & Research Challenge \\
\hline $\begin{array}{l}\text { Özdemir et al., } \\
2015 \text { [36] }\end{array}$ & $\begin{array}{l}\text { Description of trends in the electrified transport } \\
\text { logistic vehicles with their detailed technical } \\
\text { specifications. } \\
\text { Qualitative comparisons and infrastructural } \\
\text { requirements, and quantitative evaluation of the }\end{array}$ & $\begin{array}{l}\text { Electrified transport logistic vehicles; } \\
\text { Technical specifications; Fleet } \\
\text { implementation }\end{array}$ \\
\hline $\begin{array}{l}\text { Offer et al., } 2010 \\
{[41]}\end{array}$ & $\begin{array}{c}\text { lifecycle cost for battery electric vehicles (BEV), } \\
\text { hydrogen fuel cell electric vehicles (FCEV) and } \\
\text { hydrogen fuel cell plug-in hybrid vehicles } \\
\text { (FCHEV). }\end{array}$ & $\begin{array}{l}\text { Electric vehicle; Fuel cell vehicle; } \\
\text { Hybrid vehicle; Life cycle costs }\end{array}$ \\
\hline $\begin{array}{l}\text { Kelouwani et } \\
\text { al., } 2013 \text { [23] }\end{array}$ & $\begin{array}{l}\text { Implementation of an energy management } \\
\text { strategy for fuel cell plug-in hybrid electric } \\
\text { vehicles using a real-time power splitting method } \\
\text { that preserves the battery pack life. }\end{array}$ & $\begin{array}{c}\text { Electric vehicles; Energy efficiency; } \\
\text { Energy management; Fuel cells; } \\
\text { Nonlinear optimal control; Vehicle } \\
\text { dynamics }\end{array}$ \\
\hline $\begin{array}{l}\text { Sharer et al., } \\
2013 \text { [48] }\end{array}$ & $\begin{array}{l}\text { Evaluation of limitations of battery and } \\
\text { hydrogen-powered medium-duty vehicles by } \\
\text { assessing the fuel displacement and cost-benefit } \\
\text { potential of adding fuel cell systems to double the } \\
\text { current range of BEVs. }\end{array}$ & $\begin{array}{l}\text { Hydrogen-powered vehicles; Battery } \\
\text { electric vehicles; Fuel cell range } \\
\text { extender; Medium-duty vehicle } \\
\text { market; Fuel displacement; } \\
\text { Cost-benefit potential; Powertrain } \\
\text { cost; Optimized component sizing; } \\
\text { Energy management strategy }\end{array}$ \\
\hline $\begin{array}{l}\text { Jokela et al., } \\
2019 \text { [25] }\end{array}$ & $\begin{array}{l}\text { Combined model based on a component sizing } \\
\text { process with an energy management strategy } \\
\text { (EMS) optimization for determining powertrain } \\
\text { performance and total system costs focused on } \\
\text { Fuel-Cell Hybrid Electric Vehicle (FCHEV) } \\
\text { architectures for commercial vehicles. }\end{array}$ & $\begin{array}{l}\text { Component sizing; Fuel cell powered } \\
\text { vehicle; Light, Medium- and } \\
\text { heavy-duty trucks; Optimization; } \\
\text { Ownership cost }\end{array}$ \\
\hline $\begin{array}{l}\text { Sim et al., } 2019 \\
{[49]}\end{array}$ & $\begin{array}{l}\text { Component sizing algorithm to minimize overall } \\
\text { ownership cost, while ensuring the fuel } \\
\text { cell-powered commercial vehicle configuration } \\
\text { matches or exceeds the performance and cargo } \\
\text { capacity of a conventional vehicle. }\end{array}$ & $\begin{array}{l}\text { Component sizing; Fuel cell powered } \\
\text { vehicle; Medium- and heavy-duty } \\
\text { trucks; Optimization; Ownership cost }\end{array}$ \\
\hline $\begin{array}{l}\text { Walters et al., } \\
2015 \text { [24] }\end{array}$ & $\begin{array}{l}\text { Overview of the state-of-the-art in battery and } \\
\text { range extension technology, showing key issues } \\
\text { in range extender configurations development } \\
\text { working with hydrogen. } \\
\text { Study of an Extended Range Electric Vehicle } \\
\text { (EREV) based in a Fuel Cell Electric Vehicle }\end{array}$ & $\begin{array}{l}\text { Fuel Cell; Hybrid; Plug-In; Range; } \\
\text { Range-Extender }\end{array}$ \\
\hline $\begin{array}{l}\text { Fernández et al., } \\
\quad 2016 \text { [17] }\end{array}$ & $\begin{array}{l}\text { (FCEV) in order to determine the working } \\
\text { conditions that will lead to better efficiency and } \\
\text { performance, referring to capacity of both energy } \\
\text { sources }\end{array}$ & $\begin{array}{l}\text { Electric vehicle; Extended range; Fuel } \\
\text { cell }\end{array}$ \\
\hline $\begin{array}{l}\text { Wu et al., } 2019 \\
{[50]}\end{array}$ & $\begin{array}{l}\text { Component sizing of a battery electric vehicle } \\
\text { using a trailer-based demountable fuel cell range } \\
\text { extender based on user requirements }\end{array}$ & $\begin{array}{l}\text { Battery electric vehicle; Hydrogen fuel } \\
\text { cell; Range extender }\end{array}$ \\
\hline $\begin{array}{l}\text { Álvarez et al., } \\
2018 \text { [53] }\end{array}$ & $\begin{array}{l}\text { Study of an Extended Range Electric Vehicle } \\
\text { (EREV) based in a Fuel Cell Electric Vehicle } \\
\text { (FCEV) in order to determine the working } \\
\text { conditions that will lead to better efficiency and } \\
\text { performance, referring to capacity of both energy } \\
\text { sources }\end{array}$ & $\begin{array}{l}\text { Electric vehicle; Extended range; Fuel } \\
\text { cell }\end{array}$ \\
\hline $\begin{array}{l}\text { Lewis et al., } \\
2017 \text { [55] }\end{array}$ & $\begin{array}{l}\text { Sizing powertrain components (fuel cell stack } \\
\text { and battery size) using real world GPS data to } \\
\text { define routes and duty cycles, to perform vehicle } \\
\text { powertrain capabilities.to complete the most } \\
\text { demanding parcel and delivery duty cycles. }\end{array}$ & $\begin{array}{l}\text { Fuel cell; Hybrid electric vehicle; } \\
\text { Medium-duty truck }\end{array}$ \\
\hline $\begin{array}{l}\text { Ceraolo et al., } \\
2017 \text { [57] }\end{array}$ & $\begin{array}{l}\text { Comparison model to analyze conventional, full } \\
\text { electric and hybrid versions of commercial vans. }\end{array}$ & $\begin{array}{l}\text { Full electric van; Hybrid van; Cost; } \\
\text { Performance; Efficiency; Powertrain } \\
\text { layout }\end{array}$ \\
\hline
\end{tabular}


Table A4. Cont.

\begin{tabular}{|c|c|c|}
\hline Authors & Problem Addressed & Research Challenge \\
\hline $\begin{array}{c}\text { Jones et al., } 2020 \\
\text { [60] }\end{array}$ & $\begin{array}{c}\text { Study of the use of hydrogen vehicles for } \\
\text { addressing sustainability concerns in urban } \\
\text { logistics by undertaking a total cost of ownership } \\
\text { analysis. }\end{array}$ & $\begin{array}{c}\text { Alternative vehicles; Hydrogen fuel } \\
\text { cell vehicles; Freight transport; Policy; } \\
\text { Total cost of ownership; Urban } \\
\text { logistics }\end{array}$ \\
\hline $\begin{array}{l}\text { Le Duigou et al., } \\
\qquad 2014 \text { [61] }\end{array}$ & $\begin{array}{l}\text { Techno-economic comparison in terms of Total } \\
\text { Cost of Ownership (TCO) framework for ICE, } \\
\text { BEV, HEV, FCEV and FC-RE powertrains, } \\
\text { analysing the major TCO-influencing parameters. }\end{array}$ & $\begin{array}{l}\text { Battery electric vehicles; Hydrogen } \\
\text { fuel cell vehicles; Range-extender; } \\
\text { Total Cost of Ownership (TCO) }\end{array}$ \\
\hline
\end{tabular}

Table A5. Research challenges and problems addressed of studies focused on market feasibility.

\begin{tabular}{|c|c|c|}
\hline Authors & Problem Addressed & Research Challenge \\
\hline Arnhold et al., 2017 [28] & $\begin{array}{l}\text { Comparison of FCEV and BEV vehicles in } \\
\text { different categories: refueling and } \\
\text { charging infrastructure, user } \\
\text { requirements, public acceptance, energy } \\
\text { system, efficiency and energy demand. }\end{array}$ & $\begin{array}{l}\text { Advantages and barriers; FCEV; } \\
\text { BEV; Refueling infrastructure; User } \\
\text { requirements; Public acceptance; } \\
\text { Energy system }\end{array}$ \\
\hline Kleiner et al., 2017a [7] & $\begin{array}{l}\text { Analysis of market conditions where } \\
\text { alternative powertrain technologies can } \\
\text { enter the market and gain market shares. }\end{array}$ & $\begin{array}{l}\text { Electric vehicle; Freight transport; } \\
\text { Light and heavy commercial vehicle; } \\
\text { Market development; Total cost of } \\
\text { ownership (TCO); } \mathrm{CO}_{2} \text { emissions }\end{array}$ \\
\hline Wood et al., 2013 [38] & $\begin{array}{l}\text { Analysis of use small hydrogen fuel-cell } \\
\text { stacks to extend the range of battery } \\
\text { electric vehicles identifying optimal } \\
\text { component configurations for minimizing } \\
\text { life cycle costs, as well as potential future } \\
\text { scenarios where fuel cell range extended } \\
\text { vehicles where economically competitive }\end{array}$ & $\begin{array}{l}\text { Fuel cell extender range; Optimal } \\
\text { component sizing; Life cycle costs; } \\
\text { Energy management strategies }\end{array}$ \\
\hline Ruf et al., 2017 [39] & $\begin{array}{c}\text { Analysis of business cases for fuel cell } \\
\text { powered delivery vans for inner-city } \\
\text { delivery logistics }\end{array}$ & $\begin{array}{c}\text { Business Cases; Fuel cell extender } \\
\text { range; Total cost of Ownership } \\
\text { (TCO); Well to Wheel (WtW) } \\
\text { emissions }\end{array}$ \\
\hline $\begin{array}{c}\text { Van Mierlo et al., } 2006 \\
\text { [40] }\end{array}$ & $\begin{array}{c}\text { Performances comparison of hybrid } \\
\text { electric vehicles and battery electric } \\
\text { vehicles with future hydrogen fuel } \\
\text { cell-based systems which are now in R\&D } \\
\text { phase. }\end{array}$ & $\begin{array}{c}\text { Battery electric vehicles; Fuel cell } \\
\text { electric vehicles; Hybrid electric } \\
\text { vehicles; Well to wheel efficiency; } \\
\text { Delivery vans }\end{array}$ \\
\hline Baptista et al., 2010b [45] & $\begin{array}{l}\text { Analysis of the impact of the market share } \\
\text { increase of hydrogen-based light-duty } \\
\text { vehicles in terms of energy consumption } \\
\text { and } \mathrm{CO}_{2} \text { emissions. }\end{array}$ & $\begin{array}{l}\text { Fleet life cycle analysis (LCA); } \\
\text { Market penetration scenarios; } \\
\text { Plug-in hybrid fuel cell vehicle; } \\
\text { Vehicle life cycle analysis } \\
\text { Electric and hybrid powertrains: }\end{array}$ \\
\hline Kromer et al., 2007 [47] & $\begin{array}{l}\text { hybrid-electric powertrains to reduce } \\
\text { energy consumption and greenhouse gas } \\
\text { (GHG) emissions }\end{array}$ & $\begin{array}{l}\text { Light-duty fleet; Tank-to-wheel } \\
\text { energy consumption; Well-to-wheel } \\
\text { energy; GHG emissions; Cost }\end{array}$ \\
\hline $\begin{array}{c}\text { Steenberghen et al., } 2008 \\
{[8]}\end{array}$ & $\begin{array}{l}\text { Presentation of technical development } \\
\text { status, their market potential, and barriers } \\
\text { to their implementation for LPG, } \\
\text { hydrogen and biofuels-based powertrains } \\
\text { in various market segments. }\end{array}$ & $\begin{array}{l}\text { Alternative fuels; Barriers to } \\
\text { implementation; Energy policy; } \\
\text { Market incentives; Transport }\end{array}$ \\
\hline Hardman et al., 2013 [58] & $\begin{array}{l}\text { Study to bring greater clarity to the } \\
\text { characteristics of disruptive innovation of } \\
\text { battery electric and hydrogen fuel cell } \\
\text { vehicles in a way that informs on the } \\
\text { viability of these emerging technologies. }\end{array}$ & $\begin{array}{c}\text { Battery electric vehicles; Disruptive } \\
\text { technologies; Fuel cell vehicles; } \\
\text { Niche markets }\end{array}$ \\
\hline
\end{tabular}


Table A6. Research challenges and problems addressed of studies focused on environmental perspectives.

\begin{tabular}{|c|c|c|}
\hline Authors & Problem Addressed & Research Challenge \\
\hline $\begin{array}{c}\text { Bartolozzi et al., } 2013 \\
\text { [29] }\end{array}$ & $\begin{array}{l}\text { Investigation of the potential of the use of } \\
\text { hydrogen produced from renewable sources } \\
\text { as automotive fuel conducting a life cycle } \\
\text { assessment for evaluating the environmental } \\
\text { sustainability applied to a fleet of hydrogen } \\
\text { vehicles for urban commercial delivery. A } \\
\text { comparison of vehicles equipped with either } \\
\text { fuel cell, standard electric and internal } \\
\text { combustion engine is done. }\end{array}$ & $\begin{array}{l}\text { Automotive fuel; Environmental } \\
\text { sustainability; Life Cycle } \\
\text { Assessment (LCA); Renewable } \\
\text { energy }\end{array}$ \\
\hline Juan et al., 2016 [31] & $\begin{array}{l}\text { Analysis of several open research challenges } \\
\text { related to the introduction of EVs in logistics } \\
\text { and transportation (L\&T) activities, including: } \\
\text { environmental-related issues; and strategic, } \\
\text { planning and operational issues associated } \\
\text { with "standard" EVs and with } \\
\text { hydrogen-based EVs. }\end{array}$ & $\begin{array}{l}\text { Electric vehicles; Hydrogen-based } \\
\text { EVs; Green vehicle routing } \\
\text { problems; Logistics and } \\
\text { transportation; Recharge stations } \\
\text { allocation and capability; } \\
\text { Driving-range; Environmental } \\
\text { issues; Optimization problems }\end{array}$ \\
\hline Propfe et al., 2011 [37] & $\begin{array}{l}\text { Identify } \mathrm{CO}_{2} \text { potential reduction of DHL } \\
\text { delivery fleet in different scenarios based on a } \\
\text { comparison of different types of powertrains } \\
\text { running in a new developed driving cycle that } \\
\text { matches the requirements of delivery trucks. }\end{array}$ & $\begin{array}{l}\mathrm{CO}_{2} \text { efficiency; Light commercial } \\
\text { vehicles ( } \mathrm{LCV}) ; \text { Alternative drive } \\
\text { trains; Urban driving cycle }\end{array}$ \\
\hline Thomas, 2009 [42] & $\begin{array}{c}\text { Evaluation of several alternative vehicle and } \\
\text { fuel options to assess the societal benefits } \\
\text { (greenhouse gas emissions) of replacing } \\
\text { conventional gasoline cars. }\end{array}$ & $\begin{array}{l}\text { Alternative fuelled vehicles; } \\
\text { Dynamic simulation; Urban air } \\
\text { pollution }\end{array}$ \\
\hline Thomas, 2009 [43] & $\begin{array}{l}\text { Comparison of alternative transportation } \\
\text { options including hybrid electric vehicles and } \\
\text { plug-in hybrids fuelled by gasoline, diesel } \\
\text { fuel, natural gas, and ethanol, and all-electric } \\
\text { vehicles powered by either batteries or fuel } \\
\text { cells from environmental impact point of } \\
\text { view (air pollution) and oil consumption. }\end{array}$ & $\begin{array}{c}\text { Battery electric vehicle; Fuel cell } \\
\text { electric vehicle; Plug-in electric } \\
\text { vehicle; Dynamic simulation; Energy } \\
\text { security; Greenhouse gases; } \\
\text { Hydrogen infrastructure; Societal } \\
\text { cost savings }\end{array}$ \\
\hline $\begin{array}{c}\text { Baptista et al., 2010a } \\
\text { [52] }\end{array}$ & $\begin{array}{l}\text { Well-to-Wheel (WTW) Life-Cycle Analysis } \\
\text { (LCA) for two hydrogen powered vehicle } \\
\text { powertrain options (fuel cell plug-in hybrid } \\
\text { vehicle, FC-PHEV; and fuel cell hybrid } \\
\text { vehicle, HEV-FC), in comparison to the } \\
\text { conventional ICE Diesel Taxi and a full } \\
\text { electric vehicle (EV). }\end{array}$ & $\begin{array}{c}\text { Energy consumption; Fuel cell } \\
\text { hybrid vehicle; Life cycle analysis } \\
\text { (LCA) }\end{array}$ \\
\hline $\begin{array}{c}\text { Browne et al., } 2014 \\
{[54]}\end{array}$ & $\begin{array}{l}\text { Analysis of annual average distance travelled, } \\
\text { fuel consumption and } \mathrm{CO}_{2} \text { emissions for } \\
\text { electric van fleet adoption. }\end{array}$ & $\begin{array}{l}\text { Light goods vehicles; Van fleet; } \\
\text { Urban areas; Annual average } \\
\text { distance travelled; Fuel } \\
\text { consumption; Emissions; Whole life } \\
\text { costs }\end{array}$ \\
\hline $\begin{array}{l}\text { Ramachandran et al., } \\
2015 \text { [56] }\end{array}$ & $\begin{array}{l}\text { Comparison the use of alternative powertrain } \\
\text { technologies on the basis of their overall } \\
\text { efficiency and GHG emissions involved in the } \\
\text { conversion of the primary energy source to } \\
\text { the actual energy required at wheels through } \\
\text { a well-to-wheel analysis. }\end{array}$ & $\begin{array}{l}\text { Alternative fuelled vehicle; } \\
\text { Greenhouse gas (GHG) emissions; } \\
\text { Biofuels; Battery electric vehicle; } \\
\text { Fuel cell electric vehicle; Efficiency; } \\
\text { Well to wheel analysis; Electricity } \\
\text { mix; Life cycle analysis (LCA) }\end{array}$ \\
\hline $\begin{array}{l}\text { Maniatopoulos et al., } \\
2015 \text { [59] }\end{array}$ & $\begin{array}{l}\text { Review of the potential reduction of GHG } \\
\text { emissions in road transport through the total } \\
\text { replacement of petroleum-fuelled vehicles } \\
\text { with hydrogen and battery electrical vehicles. }\end{array}$ & $\begin{array}{l}\text { Battery electric vehicle; Fuel cell } \\
\text { electric vehicle; Hydrogen economy; } \\
\text { Road transport; Sustainable energy } \\
\text { strategy; GHG emissions }\end{array}$ \\
\hline
\end{tabular}


Table A7. Research challenges and problems addressed of studies focused on powertrain component sizing.

\begin{tabular}{|c|c|c|}
\hline Authors & Problem Addressed & Research Challenge \\
\hline Millo et al., 2016 [34] & $\begin{array}{l}\text { Investigation of the usage of a Fuel Cell (FC) as } \\
\text { a range extender in a full electric light duty } \\
\text { commercial vehicle in the framework of the } \\
\text { collaborative European project ARTEMIS } \\
\text { (Automotive PEMFC range extender with high } \\
\text { temperature improved stacks) }\end{array}$ & $\begin{array}{l}\text { Electric vehicle; Battery electric } \\
\text { vehicle; Fuel cell electric vehicle; } \\
\text { HT-PEM fuel cell; Range extender }\end{array}$ \\
\hline Jensen et al., 2013 [46] & $\begin{array}{l}\text { Analysis of different EV setups with FC } \\
\text { strategies are presented and compared. }\end{array}$ & $\begin{array}{l}\text { Battery electric vehicle; Fuel-cell } \\
\text { hybrid electric vehicle }\end{array}$ \\
\hline $\begin{array}{l}\text { Bendjedia et al., } 2018 \\
\text { [51] }\end{array}$ & $\begin{array}{l}\text { Study of an optimal sizing methodology for an } \\
\text { Energy Storage System (ESS) composed by a } \\
\text { fuel cell and an assistant source to show the } \\
\text { benefits of hybridization according to the range } \\
\text { in terms of weight, cost and fuel consumption. }\end{array}$ & $\begin{array}{c}\text { Energy Storage System; Fuel cell; } \\
\text { Hydrogen consumption; Sizing; } \\
\text { Energy management strategy }\end{array}$ \\
\hline
\end{tabular}

Table A8. Research challenges and problems addressed of studies focused on refueling and charging infrastructures.

\begin{tabular}{ccc}
\hline Authors & Problem Addressed & Research Challenge \\
\hline Robinius et al., 2018 [44] & $\begin{array}{c}\text { Performing a techno-economic analysis of the } \\
\text { required infrastructure for refueling battery } \\
\text { and fuel cell electric vehicles at multiple scales. }\end{array}$ & $\begin{array}{c}\text { Hydrogen Fuelling; Electric } \\
\text { Charging }\end{array}$ \\
\hline
\end{tabular}

\section{References}

1. Aditjandra, P.T.; Galatioto, F.; Bell, M.J.; Zunder, T.H. Evaluating the impacts of urban freight traffic: Application of micro-simulation at a large establishment. Eur. J. Transp. Infrastruct. Res. 2016, 16, 4-22. [CrossRef]

2. European Environment Agency (EEA). Analysing and Managing Urban Growth. Available online: https: //www.eea.europa.eu/articles/analysing-and-managing-urban-growth (accessed on 24 July 2020).

3. Seto, K.; Dhakal, S.; Bigio, A.; Blanco, H.; Delgado, G.C.; Dewar, D.; McMahon, J. Human settlements, infrastructure and spatial planning. In Climate Change 2014 Mitigation of Climate Change. IPCC Working Group III Contribution to AR5; Cambridge University Press: Cambridge, UK; New York, NY, USA, 2014. [CrossRef]

4. Cox, W. Demographia World Urban Areas E Population Projections; Wendel Cox Consultancy: St. Louis, MO, USA, 2019.

5. European Commission. Directorate General for Mobility and Transport. White Paper on Transport. Roadmap to a Single European Transport Area-Towards a Competitive and Resource-Efficient Transport System; European Commission: Brussels, Belgium, 2011. [CrossRef]

6. Gevaers, R.; van de Voorde, E.; Vanelslander, T. Cost Modelling and Simulation of Last-mile Characteristics in an Innovative B2C Supply Chain Environment with Implications on Urban Areas and Cities. Proced. Soc. Behav. Sci. 2014, 125, 398-411. [CrossRef]

7. Kleiner, F.; Friedrich, H.E. Scenario analyses for the techno-economical evaluation of the market diffusion of future commercial vehicle concepts. In Proceedings of the International Battery, Hybrid and Fuel Cell Electric Vehicle Symposium, Evs30 Symposium, Stuttgart, Germany, 9-11 October 2017; pp. 1-13.

8. Steenberghen, T.; López, E. Overcoming barriers to the implementation of alternative fuels for road transport in Europe. J. Clean. Prod. 2008, 16, 577-590. [CrossRef]

9. Pelletier, S.; Jabali, O.; Laporte, G. Goods distribution with electric vehicles: Review and research perspectives. Transp. Sci. 2016, 50, 3-22. [CrossRef]

10. Margaritis, D.; Anagnostopoulou, A.; Tromaras, A.; Boile, M. Electric commercial vehicles: Practical perspectives and future research directions. Res. Transp. Bus. Manag. 2016, 18, 4-10. [CrossRef]

11. Quak, H.; Nesterova, N.; van Rooijen, T. Possibilities and Barriers for Using Electric-powered Vehicles in City Logistics Practice. Transp. Res. Proced. 2016, 12, 157-169. [CrossRef] 
12. Christensen, L.; Klauenberg, J.; Kveiborg, O.; Rudolph, C. Suitability of commercial transport for a shift to electric mobility with Denmark and Germany as use cases. Res. Transp. Econ. 2017, 64, 48-60. [CrossRef]

13. Birky, A.K.; Laughlin, M.; Tartaglia, K.; Price, R.; Lim, B.; Lin, Z. Electrification Beyond Light Duty: Class 2b-3 Commercial Vehicles; Oak Ridge National Laboratory: Springfield, VA, USA, 2017.

14. Wang, J.; Wang, H.; Fan, Y. Techno-Economic Challenges of Fuel Cell Commercialization. Engineering 2018, 4, 352-360. [CrossRef]

15. Biresselioglu, M.E.; Demirbag Kaplan, M.; Yilmaz, B.K. Electric mobility in Europe: A comprehensive review of motivators and barriers in decision making processes. Transp. Res. Part A Policy Pract. 2018, 109, 1-13. [CrossRef]

16. Wang, M.; Thoben, K.D.; Bernardo, M.; Daudi, M. Diversity in Employment of Electric Commercial Vehicles in Urban Freight Transport: A Literature Review. Logist. Res. 2018, 11, 1-21. [CrossRef]

17. Fernández, R.Á.; Cilleruelo, F.B.; Martínez, I.V. A new approach to battery powered electric vehicles: A hydrogen fuel-cell-based range extender system. Int. J. Hydrog. Energy 2016, 41, 4808-4819. [CrossRef]

18. Olsson, J.; Hellström, D.; Pålsson, H. Framework of Last Mile Logistics Research: A Systematic Review of the Literature. Sustainability 2019, 11, 7131. [CrossRef]

19. European Automobile Manufacturers Association (ACEA). Vehicles In Use-Europe 2018; European Automobile Manufacturers Association: Brussels, Belgium, 2018; pp. 1-19.

20. Kelouwani, S.; Agbossou, K.; Dubé, Y.; Boulon, L. Fuel cell plug-in hybrid electric vehicle anticipatory and real-time blended-mode energy management for battery life preservation. J. Power Sources 2013, 221, 406-418. [CrossRef]

21. Walters, M.; Kuhlmann, A.; Ogrzewalla, J. Fuel cell range extender for battery electric vehicles. In Proceedings of the International Conference on Electrical Systems for Aircraft, Railway, Ship Propulsion and Road Vehicles (ESARS), Aagen, Germany, 3-5 March 2015; pp. 5-10. [CrossRef]

22. Jokela, T.; Iraklis, A.; Kim, B.; Gao, B. Combined Sizing and EMS Optimization of Fuel-Cell Hybrid Powertrains for Commercial Vehicles. In Proceedings of the WCX SAE World Congress Experience, Detroit, MI, USA, 9-11 April 2019; pp. 1-13. [CrossRef]

23. Paré, G.; Trudel, M.C.; Jaana, M.; Kitsiou, S. Synthesizing information systems knowledge: A typology of literature reviews. Inf. Manag. 2015, 52, 183-199. [CrossRef]

24. Mulrow, C. Systematic Reviews: Rationale for systematic reviews. BMJ 1994, 309, 597-599. [CrossRef]

25. Moher, D.; Liberati, A.; Tetzlaff, J.; Altman, D.G.; Altman, D.; Antes, G.; Atkins, D.; Barbour, V.; Barrowman, N.; Berlin, J.A.; et al. Preferred reporting items for systematic reviews and meta-analyses: The PRISMA statement. PLoS Med. 2009, 6, e1000097. [CrossRef]

26. Halevi, G.; Moed, H.; Bar-Ilan, J. Suitability of Google Scholar as a source of scientific information and as a source of data for scientific evaluation-Review of the Literature. J. Informetr. 2017, 11, 823-834. [CrossRef]

27. Adebusuyi, A.; Ashwood, L. A review of 3 hybridization options for light commercial and passenger vehicles. In Proceedings of the International Conference on Electrical Systems for Aircraft, Railway and Ship Propulsion (ESARS), Bologna, Italy, 16-18 October 2012; pp. 7-10. [CrossRef]

28. Arnhold, O.; Grüger, F.; Wanitschke, A.; Goldammer, K. Debate and appeal role of hydrogen and battery electric vehicles in mobility. ATZelektronik Worldw. 2017, 12, 16-21. [CrossRef]

29. Bartolozzi, I.; Rizzi, F.; Frey, M. Comparison between hydrogen and electric vehicles by life cycle assessment: A case study in Tuscany, Italy. Appl. Energy 2013, 101, 103-111. [CrossRef]

30. Bergmann, D.; Wedowski, S.; Maiterth, J.; Marten, C.; Ghetti, S.; Walters, M.; Morra, P. Range extender systems for electric drivetrains in medium duty distribution vehicles. In Proceedings of the Internationaler Motorenkongress, Baden, Germany, 21-22 February 2017; pp. 703-721. [CrossRef]

31. Juan, A.A.; Mendez, C.A.; Faulin, J.; de Armas, J.; Grasman, S.E. Electric vehicles in logistics and transportation: A survey on emerging environmental, strategic, and operational challenges. Energies 2016, 9, 86. [CrossRef]

32. Kleiner, F.; Friedrich, H.E. Maintenance \& repair cost calculation and assessment of resale value for different alternative commercial vehicle powertrain technologies. In Proceedings of the International Battery, Hybrid and Fuel Cell Electric Vehicle Symposium, EVS30 Symposium, Stuttgart, Germany, 9-11 October 2017; pp. 1-16. 
33. Kleiner, F.; Özdemir, E.D.; Schmid, S.A.; Beermann, M.; Çatay, B.; Moran, B.; Lim, O.T.; Friedrich, H.E. Electrification of Transport Logistic Vehicles: A Techno-Economic Assessment of Battery and Fuel Cell Electric Transporter. In Proceedings of the 2015 EVS28 International Electric Vehicle Symposium and Exhibition (EVS 2015), Kintex, Korea, 3-6 May 2015; pp. 1-11.

34. Millo, F.; Caputo, S.; Piu, A. Analysis of a HT-PEMFC range extender for a light duty full electric vehicle (LD-FEV). Int. J. Hydrog. Energy 2016, 41, 16489-16498. [CrossRef]

35. Ntziachristos, L.; Panagiota, D. Sustainability Assessment of Road Transport Technologies; European Commission; Joint Research Centre: Ispra, Italy, 2012. [CrossRef]

36. Özdemir, E.D.; Kleiner, F.; Beermann, M.; Çatay, B.; Beers, E.; Moran, B.; Lim, O.T.; Schmid, S.A. Status and trends for electrified transport logistic vehicles. In Proceedings of the European Battery, Hybrid and Fuel Cell Electric Vehicle Congress, Brussels, Belgium, 2-4 December 2015; pp. 1-8.

37. Propfe, B.; Schlaghecken, G.; Jüchter, A.; Schmid, S.A. Identifying the potential $\mathrm{CO}_{2}$-efficiency for the Deutsche Post DHL delivery fleet based on vehicle technology scenarios. In Proceedings of the European Electric Vehicle Congress, Brussels, Belgium, 26-28 October 2011; pp. 1-6.

38. Wood, E.; Wang, L.; Gonder, J.; Ulsh, M. Overcoming the Range Limitation of Medium-Duty Battery Electric Vehicles through the use of Hydrogen Fuel-Cells. SAE Int. J. Commer. Veh. 2013, 6, 563-574. [CrossRef]

39. Ruf, Y.; Kaufmann, M.; Lange, S.; Pfister, J.; Heieck, F.; Endres, A. Fuel Cells and Hydrogen Applications for Regions and Cities; Roland Berger: Brussels, Belgium; Frankfurt, Germany, 2017.

40. Van Mierlo, J.; Maggetto, G.; Lataire, P. Which energy source for road transport in the future? A comparison of battery, hybrid and fuel cell vehicles. Energy Convers. Manag. 2006, 47, 2748-2760. [CrossRef]

41. Offer, G.J.; Howey, D.; Contestabile, M.; Clague, R.; Brandon, N.P. Comparative analysis of battery electric, hydrogen fuel cell and hybrid vehicles in a future sustainable road transport system. Energy Policy 2010, 38, 24-29. [CrossRef]

42. Thomas, C.E. Fuel cell and battery electric vehicles compared. Int. J. Hydrog. Energy 2009, 34, 6005-6020. [CrossRef]

43. Thomas, C.E. Transportation options in a carbon-constrained world: Hybrids, plug-in hybrids, biofuels, fuel cell electric vehicles, and battery electric vehicles. Int. J. Hydrog. Energy 2009, 34, 9279-9296. [CrossRef]

44. Robinius, M.; Linßen, J.; Grube, T.; Reuß, M.; Stenzel, P.; Syranidis, K.; Kuckertz, P.; Stolten, D. Comparative Analysis of Infrastructures: Hydrogen Fueling and Electric Charging of Vehicles; Energy \& Environment: Leipzig, Germany, 2018.

45. Baptista, P.; Tomás, M.; Silva, C. Plug-in hybrid fuel cell vehicles market penetration scenarios. Int. J. Hydrog. Energy 2010, 35, 10024-10030. [CrossRef]

46. Jensen, H.C.B.; Schaltz, E.; Koustrup, P.S.; Andreasen, S.J.; Kær, S.K. Evaluation of fuel-cell range extender impact on hybrid electrical vehicle performance. IEEE Trans. Veh. Technol. 2013, 62, 50-60. [CrossRef]

47. Kromer, M.A.; Heywood, J.B. Electric Powertrains: Opportunities and Challenges in the U.S. Light-Duty Vehicle Fleet; Sloan Automotive Laboratory: Cambridge, MA, USA, 2007.

48. Sharer, P.; Rousseau, A. Benefits of fuel cell range extender for medium-duty vehicle applications. World Electr. Veh. J. 2013, 6, 452-463. [CrossRef]

49. Sim, K.; Vijayagopal, R.; Kim, N.; Rousseau, A. Optimization of component sizing for a fuel cell-powered truck to minimize ownership cost. Energies 2019, 12, 1125. [CrossRef]

50. Wu, D.; Ren, J.; Davies, H.; Shang, J.; Haas, O. Intelligent hydrogen fuel cell range extender for battery electric vehicles. World Electr. Veh. J. 2019, 10, 29. [CrossRef]

51. Bendjedia, B.; Rizoug, N.; Boukhnifer, M.; Bouchafaa, F.; Benbouzid, M. Influence of secondary source technologies and energy management strategies on Energy Storage System sizing for fuel cell electric vehicles. Int. J. Hydrog. Energy 2018, 43, 11614-11628. [CrossRef]

52. Baptista, P.; Ribau, J.; Bravo, J.; Silva, C.; Adcock, P.; Kells, A. Fuel cell hybrid taxi well-to-wheel life-cycle analysis. In Proceedings of the EVS25 World Battery, Hybrid and Fuel Cell Electric Vehicle Symposium, Shenzhen, China, 5-9 November 2010; pp. 798-803. [CrossRef]

53. Álvarez, R.; Corbera, S. Hydrogen fuel cell as range extender in Electric Vehicle Powertrains: Fuel optimization strategies. In Nanostructured Materials for Next-Generation Energy Storage and Conversion; Springer: Heidelberg, Germany, 2018; pp. 359-383.

54. Browne, M.; Rizet, C.; Allen, J. A Comparative Assessment of the Light Goods Vehicle Fleet and the Scope to Reduce its $\mathrm{CO}_{2}$ Emissions in the UK and France. Proced. Soc. Behav. Sci. 2014, 125, 334-344. [CrossRef] 
55. Lewis, M.; Hearn, C.; Feng, X.; Hanlin, J.; Levin, J.; Ambrosio, J.; Guggenheim, P.; Walker, C. Design and modeling for hydrogen fuel cell conversion of parcel delivery trucks. In Proceedings of the 2017 IEEE Transportation Electrification Conference and Expo (ITEC), Chicago, IL, USA, 22-24 June 2017; pp. 674-678. [CrossRef]

56. Ramachandran, S.; Stimming, U. Well to wheel analysis of low carbon alternatives for road traffic. Energy Environ. Sci. 2015, 8, 3313-3324. [CrossRef]

57. Ceraolo, M.; Lutzemberger, G.; Sani, L.; Valenti, G.; Pretto, A.; Pugi, L. Full electric and hybrid series vans: Cost, performance and efficiency evaluation for different powertrain layout. In Proceedings of the 2017 International Conference of Electrical and Electronic Technologies for Automotive, Torino, Italy, 15 June 2017. [CrossRef]

58. Hardman, S.; Steinberger-Wilckens, R.; van der Horst, D. Disruptive innovations: The case for hydrogen fuel cells and battery electric vehicles. Int. J. Hydrog. Energy 2013, 38, 15438-15451. [CrossRef]

59. Maniatopoulos, P.; Andrews, J.; Shabani, B. Towards a sustainable strategy for road transportation in Australia: The potential contribution of hydrogen. Renew. Sustain. Energy Rev. 2015, 52, 24-34. [CrossRef]

60. Jones, J.; Genovese, A.; Tob-Ogu, A. Hydrogen vehicles in urban logistics: A total cost of ownership analysis and some policy implications. Renew. Sustain. Energy Rev. 2020, 119, 1-15. [CrossRef]

61. Le Duigou, A.; Smatti, A. On the comparison and the complementarity of batteries and fuel cells for electric driving. Int. J. Hydrog. Energy 2014, 39, 17873-17883. [CrossRef]

62. De Cauwer, C.; Messagie, M.; Heyvaert, S.; Coosemans, T.; van Mierlo, J. Electric vehicle use and energy consumption based on real world electric vehicle fleet trip and charge data its impact on existing EV research models. World Electr. Veh. J. 2015, 7, 436-446.

63. Fetene, G.M.; Kaplan, S.; Mabit, S.L.; Jensen, A.F.; Prato, C.G. Harnessing big data for estimating the energy consumption and driving range of electric vehicles. Transp. Res. Part D Transp. Environ. 2017, 54, 1-11. [CrossRef]

64. Fiori, C.; Marzano, V. Modelling energy consumption of electric freight vehicles in urban pickup/delivery operations: Analysis and estimation on a real-world dataset. Transp. Res. Part D Transp. Environ. 2018, 65, 658-673. [CrossRef]

65. Hosseini, S.E.; Wahid, M.A. Hydrogen production from renewable and sustainable energy resources: Promising green energy carrier for clean development. Renew. Sustain. Energy Rev. 2016, 57, 850-866. [CrossRef]

(C) 2020 by the authors. Licensee MDPI, Basel, Switzerland. This article is an open access article distributed under the terms and conditions of the Creative Commons Attribution (CC BY) license (http://creativecommons.org/licenses/by/4.0/). 